\title{
Enriching WPCs and NFPCs with Carbon Nanotubes and Graphene
}

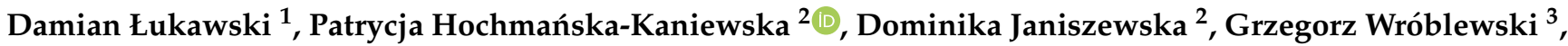 \\ Jeff Patmore ${ }^{4}$ and Agnieszka Lekawa-Raus ${ }^{3, *}$
}

1 Institute of Physics, Faculty of Materials Engineering and Technical Physics, Poznan University of Technology, Piotrowo 3, 61-139 Poznan, Poland; damian.lukawski@put.poznan.pl

2 Wood Technology Centre, Łukasiewicz Research Network-Poznań Institute of Technology, ul. Winiarska 1, 60-654 Poznan, Poland; patrycja.hochmanska@pit.lukasiewicz.gov.pl (P.H.-K.); dominika.janiszewska@pit.lukasiewicz.gov.pl (D.J.)

3 Faculty of Mechatronics, Warsaw University of Technology, ul. św. Andrzeja Boboli 8, 02-525 Warszawa, Poland; grzegorz.wroblewski1@pw.edu.pl

4 Pembroke College, University of Cambridge, Trumpington St., Cambridge CB2 1RF, UK; jjp43@cam.ac.uk

* Correspondence: agnieszka.raus@pw.edu.pl

check for updates

Citation: Łukawski, D.;

Hochmańska-Kaniewska, P.; Janiszewska, D.; Wróblewski, G.; Patmore, J.; Lekawa-Raus, A Enriching WPCs and NFPCs with Carbon Nanotubes and Graphene. Polymers 2022, 14, 745. https:// doi.org/10.3390/polym14040745

Academic Editors: Emmanuel Akpan Suchart Siengchin and Bernd Wetzel

Received: 29 December 2021

Accepted: 10 February 2022

Published: 15 February 2022

Publisher's Note: MDPI stays neutral with regard to jurisdictional claims in published maps and institutional affiliations.

Copyright: (C) 2022 by the authors. Licensee MDPI, Basel, Switzerland. This article is an open access article distributed under the terms and conditions of the Creative Commons Attribution (CC BY) license (https:// creativecommons.org/licenses/by/ $4.0 /)$.

\begin{abstract}
Carbon nanotubes (CNTs) and graphene, with their unique mechanical, electrical, thermal, optical, and wettability properties, are very effective fillers for many types of composites. Recently, a number of studies have shown that CNTs and graphene may be integrated into wood-plastic composites (WPCs) and natural-fibre-reinforced polymer composites (NFPCs) to improve the existing performance of the WPCs/NFPCs as well as enabling their use in completely new areas of engineering. The following review analyses the results of the studies presented to date, from which it can be seen that that inclusion of CNTs/graphene may indeed improve the mechanical properties of the WPCs/NFPCs, while increasing their thermal conductivity, making them electroconductive, more photostable, less sensitive to water absorption, less flammable, and more thermally stable. This study indicates that the composition and methods of manufacturing of hybrid WPCs/NFPCs vary significantly between the samples, with a consequent impact on the level of improvement of specific properties. This review also shows that the incorporation of CNTs/graphene may enable new applications of WPCs/NFPCs, such as solar thermal energy storage devices, electromagnetic shielding, antistatic packaging, sensors, and heaters. Finally, this paper recognises key challenges in the study area, and proposes future work.
\end{abstract}

Keywords: wood-plastic composites; natural fibre-plastic composites; carbon nanotubes; MWCNTs; graphene; graphene oxide; graphene nanoplatelets; hybrid composites

\section{Introduction}

Wood-plastic composites (WPCs) entered the market in the 1990s; they are usually composed of up to $50 \% w / w$ of wood flour, thermoplastic polymers (polypropylene, polyethylene, polyvinyl chloride etc.), and small amounts of additives such as dyes or coupling agents [1]. WPCs are most often used in construction and flooring, replacing lumber, wood-based boards (WBBs), ceramic tiles, or metals. WPCs can be designed for specific performance requirements, taking into account the advantages of the natural strength of the wood and the hydrophobic characteristics of the plastic component. The possibility of use of wood waste fillers as well as waste and recycled plastics reduces the environmental impact of the material, and also improves the circular economy [2-4]. Other advantages of WPCs are their ease of maintenance, improved durability, and substantial service lifetime [5]. The large weight share of polymers enables the shaping of WPC elements by moulding. Moulding allows the formation of complex shapes that would be very costly or even impossible to produce with pure lumber, wood-based boards (WBBs), 
or stone/ceramics. Furthermore, ready-made WPCs may be further shaped using the same tools as conventional lumber.

However, WPCs are also not free from disadvantages. The large weight share of the polymer matrix also predetermines the mechanical properties of the WPCs, which are close to those of their base polymers; therefore, they are poorer than (for example) raw wood. Another negative property that has been observed in WPCs is their susceptibility to environmental degradation. This type of degradation can occur as a result of various factors, including temperature, air quality, moisture (the polymer matrix does not fully exclude water interaction), microorganisms, light, high-energy radiation, chemical agents, and mechanical stress [6,7]. These factors can decrease the aesthetic quality (discoloration) and mechanical strength of WPCs $[1,8,9]$. Moreover, evidence has been seen of the presence of fungal attack on WPC boards that are exposed to natural weathering [10,11].

Even taking account of these issues, the current wide use of WPCs, coupled with their composite nature, favours the development of research in this area. Very often, the studies are extended to the use of other cellulose-rich materials (e.g., milled straw, plant shells, or bamboo) as fillers [12]. The latter composites are referred to as natural fibre-polymer composites (sometimes WPCs are classified as subgroup of NFPCs). NFPCs are not yet widely applied, as up to this point their performance has often been found to be less than satisfactory [12]. However, new studies in this area show very encouraging results [13-18]. Other studies focus mainly on the improvement of the performance of the WPCs, utilisation of new types of matrices, new manufacturing techniques, and an increase in the range of applications [19-23]. One of the notable interesting areas of study is in the enrichment of the WPC and NFPC composites with carbon nanomaterials, such as carbon nanotubes (CNTs) and graphene.

Both carbon nanotubes and graphene are nano-allotropes of pure carbon [24,25]. The structure of both is based on a planar hexagonal lattice of $\mathrm{sp}^{2}$-bonded carbon atoms (Figure 1a), i.e., every carbon atom forms a strong covalent bond with three neighbouring carbon atoms, and a much weaker pi bond is formed by the atoms laterally by their fourth available electrons distributed in $p_{z}$ orbitals perpendicular to the hexagonal plane. This atomic structure imparts both CNTs and graphene with extremely high mechanical strength and stiffness, as well as superior electrical and thermal conductivity [26]. Additionally, both of these nanomaterials are lightweight [27], superhydrophobic [28,29], chemically resistant [30], and environmentally friendly, as they may be synthesised from greenhouse gases such as methane or $\mathrm{CO}_{2}[31,32]$.

a)

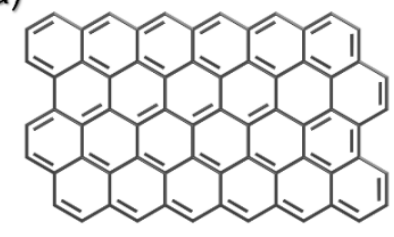

d)

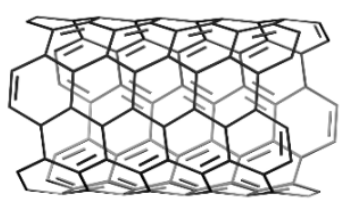

b)

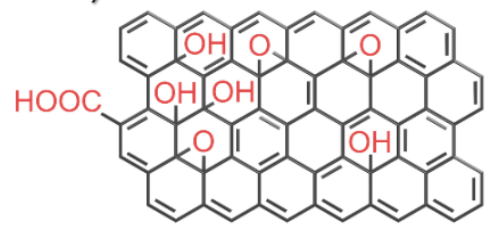

c)

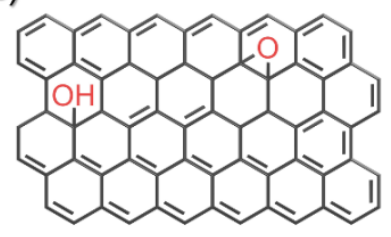

e)

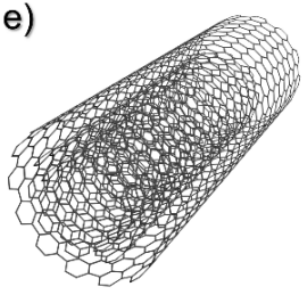

f)

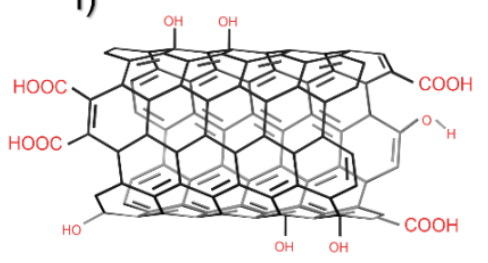

Figure 1. Structure of (a) graphene, (b) graphene oxide, (c) reduced graphene oxide, (d) singlewalled carbon nanotube (e) multiwalled carbon nanotube, and (f) functionalised carbon nanotube. Annotation indicates where the structure is not pure carbon. 
Graphene is a 2D structure that, in theory, is one atomic layer thick (Figure 1a). In practice, the name graphene often refers to the whole family of two-dimensional carbon nanomaterials. The material to mention first in the context of WPCs is graphene nanoplatelets (GNPs); these are multilayered pure graphene structures often produced by the exfoliation of graphite, or via the chemical vapour deposition (CVD) process. Although the properties of GNPs may not be superior to those of single-layer graphene, they are sufficient to improve the properties of many polymer composites [33]. GNPs are also quite inexpensive, easy to handle, and are produced and sold in large quantities. A further material is graphene oxide (GO) (Figure $1 \mathrm{~b}$ ), which is a disordered single- or multilayered graphene functionalised with epoxy bridges, hydroxyl groups, and carboxyl groups [34]. GO is electrically insulating, and has a much poorer mechanical performance than graphene/GNPs, but it is also a chemically active and hydrophilic structure; this enables dispersion in water and a uniform distribution in many polymers [35]. Finally, reduced graphene oxide $(\mathrm{rGO})$ is a material formed by the chemical reduction of $\mathrm{GO}$. This process partially restores the electrical and mechanical properties of the graphene via the removal of most of the functional groups and the recovery of the $\mathrm{sp}^{2}$ carbon-carbon bonds (Figure 1c) [36]. Often, the reduction process is performed after the composite manufacturing process, so as to benefit from the chemical reactivity of $\mathrm{GO}$ during manufacture and the electrical and mechanical properties of graphene in the final product.

Carbon nanotubes are one-dimensional structures of seamlessly rolled-up graphene sheets; they may be referred to as single-walled carbon nanotubes (SWCNTs) if made of a single layer of graphene (Figure 1d), or multiwalled carbon nanotubes (MWCNTs) if two or more SWCNTs are encapsulated within one another (Figure 1e). SWCNTs are often characterised as having better properties than MWCNTs, but the MWCNTs can be produced inexpensively and on a large scale [31]. The CNTs may also be produced in a functionalised form to facilitate the dispersion of these structures in polymer matrices (Figure 1f) [37]. As 1D structures, the CNTs have nanosized diameters, and are most often nano- or micrometre lengths. In composites, CNTs form percolation networks more easily than graphene, but in some processes it is more difficult to obtain their high loading fractions [38,39].

Both graphene and CNTs have been widely used in composites [40]; they have been tested as fillers in many types of matrices, including polymers [39,41], metals [42], and ceramics [43]. Polymer composites were actually the first major area in which CNTs and graphene found commercial applications. Both nanomaterials have been used to enhance mechanical properties [44], improve thermal stability [45], decrease flammability [46,47], introduce electrical and thermal conductivity [39], and much more [48]. The applications of these composites include strong and lightweight construction materials [43], electromagnetic shielding [49], antistatic surfaces [50], sensors [51], components such as supercapacitors, etc. [52]. It may therefore be expected that a combination of WPCs and other NFPCs with CNTs and/or graphene may produce materials with very interesting performance parameters, suitable for completely new applications.

The following study focuses on the literature presented to date in the area of WPC/NFPCs enriched with CNMs. The study shows the potential ways in which CNMs can improve the performance of NFPCs, and analyses the factors that may influence the properties of the NFPC-CNM hybrid composites. The properties studied to date are covered in Sections 2.1-2.6 (2.1 Mechanical Properties; 2.2 Electrical and Thermal Properties; 2.3 Photostability; 2.4 Water Absorption and Swelling Thickness; 2.5 Thermal Stability and Flammability; 2.6 Foaming Efficiency). Finally, the study provides examples of new applications that may be targeted as a result of the addition of this new filler.

\section{Improvement of WPC/NFPC Performance by the Addition of Carbon Nanomaterials}

The existing literature indicates that enriching WPCs and NFPCs with carbon nanomaterials may be highly beneficial to the performance of the WPCs/NFPCs. Expanding on this, in general, it has been shown that the addition of graphene or carbon nanotubes may result in an improvement of mechanical properties [53-56], an increase in electrical 
and thermal conductivity [57-60], a decrease in water absorption, and an improvement of thermal stability $[61,62]$ and/or fire retardancy [60]. All of these tested properties are listed in Table 1.

Table 1. Carbon-nanomaterial-reinforced wood-plastic composites developed in recent years.

\begin{tabular}{|c|c|c|c|c|c|c|}
\hline Publication & CNM & Filler & Polymer & $\begin{array}{l}\text { Other } \\
\text { Additives }\end{array}$ & $\begin{array}{c}\text { Method of } \\
\text { Production * }\end{array}$ & Properties Investigated \\
\hline Sheshmani et al. [63] & $\begin{array}{c}\text { Graphene } \\
(0.2,0.4,0.6,0.8,1,2 \\
4 \text { or } 5 \text { wt. } \%)\end{array}$ & $\begin{array}{l}\text { Poplar flour } \\
\text { (20 wt.\%) }\end{array}$ & $\begin{array}{c}\mathrm{PP} \\
(72-77 \text { wt. } \%)\end{array}$ & $\begin{array}{l}\text { MAPP }(3 \\
\text { wt. } \%)\end{array}$ & A & $\begin{array}{l}\text { Mechanical properties; } \\
\text { thermal stability }\end{array}$ \\
\hline Ye et al. [61] & $\begin{array}{l}\mathrm{GO}(0.1,0.2,0.3 \\
\quad \text { and } 0.4 \%)\end{array}$ & Poplar powder & PP (60 wt. \%) & PEI & $\mathrm{D}$ & $\begin{array}{l}\text { Mechanical testing; electrical } \\
\text { conductivity; } \\
\text { water absorption }\end{array}$ \\
\hline Nourbakhsh et al. [54] & $\begin{array}{l}\text { MWCNT }(1.5,2.5 \text { or } \\
3.5 \text { wt. } \%)\end{array}$ & $\begin{array}{c}\text { Poplar fibres } \\
(40 \text { wt. } \%) \text { or bagasse } \\
\text { stalk (40 wt. } \%)\end{array}$ & $\begin{array}{c}\text { PP } \\
(53.5-60 \text { wt. } \%)\end{array}$ & $\begin{array}{l}\text { MAPP } \\
(3 \text { wt. } \%)\end{array}$ & A & Mechanical properties \\
\hline Ge et al. [64] & $\begin{array}{c}\text { CNTs, graphene, } \\
\text { activated carbon, or } \\
\text { bamboo charcoal } \\
(2 \text { wt. } \%)\end{array}$ & $\begin{array}{l}\text { Decayed particles } \\
(30,40 \text {, or } 50 \text { wt. } \%)\end{array}$ & $\begin{array}{c}\text { PVC } \\
(50,60,70 \text { wt. } \%)\end{array}$ & $\begin{array}{l}\text { Chitosan } \\
(3 \text { wt.\%) }\end{array}$ & $\mathrm{A}$ & $\begin{array}{l}\text { Mechanical properties; } \\
\text { thermal stability }\end{array}$ \\
\hline Peng et al. [65] & $\begin{array}{l}\text { MWCNTs, graphite } \\
\text { or carbon black } \\
(2 \text { wt. } \%)\end{array}$ & Wood flour (40 wt.\%) & PP (60 wt. \%) & none & A & $\begin{array}{l}\text { Weathering durability; } \\
\text { mechanical properties; } \\
\text { washing resistance }\end{array}$ \\
\hline Al-Maqdasi et al. [66] & $\begin{array}{c}\text { Masterbatches of } \\
\text { GNP oxidised at the } \\
\text { edges }(7.6,9.6 \text { and } \\
15 \text { wt. } \%)\end{array}$ & $\begin{array}{l}\text { Sawdust of spruce } \\
\text { and pine } \\
\text { (25 and } 40 \text { wt.\%) }\end{array}$ & $\begin{array}{l}\text { HDPE } \\
(43.5-58.5 \text { wt. } \%)\end{array}$ & $\begin{array}{c}\text { MAPE } \\
(1,1.5 \text { wt. } \%)\end{array}$ & B & $\begin{array}{l}\text { Mechanical properties; } \\
\text { thermal properties }\end{array}$ \\
\hline Al-Maqdasi et al. [53] & $\begin{array}{l}\text { GNP Masterbatches } \\
(0,7.6,15 \text { wt. } \%)\end{array}$ & $\begin{array}{l}\text { Sawdust of spruce } \\
(40 \mathrm{wt} . \%)\end{array}$ & $\begin{array}{c}\text { HDPE } \\
(43.5-58.5 \text { wt. } \%)\end{array}$ & $\begin{array}{c}\text { MAPE } \\
(1.5 \text { wt. } \%)\end{array}$ & B & $\begin{array}{l}\text { Mechanical properties; } \\
\text { thermal properties }\end{array}$ \\
\hline Zhang et al. [55] & MWCNT (0.1wt.\%) & $\begin{array}{l}\text { Pine wood powder } \\
\quad(\sim 15 \text { wt. } \%)\end{array}$ & $\begin{array}{l}\text { (PES) (approx. } \\
85 \text { wt. } \% \text { ) }\end{array}$ & none & $\mathrm{C}$ & Mechanical properties \\
\hline Kaymakci et al. [67] & $\begin{array}{l}\text { MWCNT }(0 \text { or } 1,3, \\
5 \text { wt. } \%)\end{array}$ & Pine flour (50 wt.\%) & PP (50 wt.\%) & $\begin{array}{l}\text { MAPP } \\
(3 \text { wt. } \%)\end{array}$ & A & $\begin{array}{l}\text { Surface roughness; wettability; } \\
\text { scratch resistance }\end{array}$ \\
\hline Zhang et al. [57] & $\begin{array}{c}\text { MWCNTs, flake } \\
\text { graphite, or carbon } \\
\text { black } \\
(3,6,9,12 \text { wt. } \%)\end{array}$ & $\begin{array}{l}\text { Poplar fibres } \\
\text { (52-60 wt.\%) }\end{array}$ & $\begin{array}{c}\text { PE } \\
(36-40 \text { wt. } \%)\end{array}$ & $\begin{array}{l}\text { MAPE } \\
(3 \text { wt. } \%)\end{array}$ & A & $\begin{array}{l}\text { Mechanical properties; } \\
\text { electrical conductivity }\end{array}$ \\
\hline Rajan et al. [59] & GNP $(0,5,10,15$ wt. $\%)$ & $\begin{array}{l}\text { Spruce and fir wood } \\
\text { flour (20 wt. } \%)\end{array}$ & $\begin{array}{c}\text { PP } \\
(65-80 \text { wt. } \%)\end{array}$ & $\begin{array}{l}\text { MAPP } \\
(3 w t . \%)\end{array}$ & A & $\begin{array}{l}\text { Electrical conductivity; } \\
\text { mechanical properties; } \\
\text { thermal properties }\end{array}$ \\
\hline Zhang et al. [60] & $\begin{array}{c}\text { GNP }(0,3,6,9 \\
12 \text { wt. } \%)\end{array}$ & $\begin{array}{l}\text { Poplar wood } \\
\text { fibres(40 wt. } \%)\end{array}$ & $\begin{array}{c}\text { PE } \\
(45-57 \text { wt. } \%)\end{array}$ & $\begin{array}{l}\text { MAPE } \\
(3 \text { wt. } \%)\end{array}$ & B & Thermal properties \\
\hline Zhang et al. [68] & $\begin{array}{l}\text { MWCNTs }(0,3,6,9 \\
12 \text { wt. } \%)\end{array}$ & $\begin{array}{l}\text { Poplar wood fibres } \\
(60 \mathrm{wt} . \%)\end{array}$ & $\begin{array}{c}\text { PE } \\
(25-37 \text { wt. } \%)\end{array}$ & $\begin{array}{l}\text { MAPE } \\
(3 \text { wt. } \%)\end{array}$ & A & $\begin{array}{l}\text { Thermal properties; } \\
\text { mechanical properties }\end{array}$ \\
\hline Fu et al. [62] & $\begin{array}{c}\text { Pure CNTs or } \\
\text { CNTs-OH }(0.5,1 \text { or } \\
2 \text { wt. } \%)\end{array}$ & $\begin{array}{l}\text { Sawdust of poplar } \\
\text { (40 wt.\%), }\end{array}$ & $\begin{array}{c}\text { PP } \\
(48-50 \text { wt. } \%)\end{array}$ & $\begin{array}{l}\text { MAPP } \\
(10 w t . \%)\end{array}$ & A & $\begin{array}{l}\text { Flammability; } \\
\text { thermal stability }\end{array}$ \\
\hline Ghalehno et al. [69] & $\mathrm{GNP}(0,1,2,4 \mathrm{phr})$ & $\begin{array}{l}\text { Wood flou61r } \\
\text { (50 wt.\%) }\end{array}$ & $\begin{array}{l}\text { HDPE } \\
(50 \text { wt. } \%)\end{array}$ & $\begin{array}{c}\text { MAPE, } \mathrm{ZnO} \\
(0-3 \text { wt. } \%)\end{array}$ & B & Mechanical properties \\
\hline Kumar et al. [70] & GNP (0.5wt.\%) & $\begin{array}{c}\text { Alkalised wood } \\
\text { powder }(0,2.5,5,7.5, \\
10 \text { wt. } \%)\end{array}$ & $\begin{array}{l}\text { Epoxy resin } \\
(89.5-99.5 \text { wt. } \%)\end{array}$ & $\begin{array}{l}\text { Hardener } \\
\text { HY-951 }\end{array}$ & $\mathrm{D}$ & $\begin{array}{l}\text { Thermal, } \\
\text { mechanical, and electrochemical } \\
\text { properties }\end{array}$ \\
\hline Zhang et al. [56] & $\begin{array}{c}\text { Flake graphite } \\
(0,5,10,15,20 \text { wt. } \%)\end{array}$ & $\begin{array}{l}\text { Poplar fibres } \\
\text { (50 wt.\%) }\end{array}$ & $\begin{array}{c}\mathrm{PE} \\
(27-47 \text { wt. } \%)\end{array}$ & $\begin{array}{l}\text { MAPE } \\
(3 \text { wt. } \%)\end{array}$ & A & $\begin{array}{l}\text { Thermal properties; } \\
\text { mechanical properties }\end{array}$ \\
\hline Lu et al. [71] & $\begin{array}{c}\mathrm{GO}(0.2,0.4,0.8 \\
1.2 \text { wt. } \%)\end{array}$ & $\begin{array}{c}\text { pine powder } \\
(4.8-28.8 \text { wt. } \%)\end{array}$ & $\begin{array}{c}\text { PU } \\
\text { (70-95 wt.\%) }\end{array}$ & None & $\mathrm{D}$ & Thermal properties \\
\hline Yaghoobi et al. [72] & $\begin{array}{l}\text { MWCNT }(0.5,1.0 \\
1.5,2.0 \text { wt. } \%)\end{array}$ & $\begin{array}{l}\text { Kenaf fibre78 } \\
\text { (30 wt.\%) }\end{array}$ & PP(63-70 wt.\%) & $\begin{array}{l}\text { MAPP } \\
(5 \text { wt. } \%)\end{array}$ & A & $\begin{array}{c}\text { Mechanical properties; } \\
\text { thermal storage; } \\
\text { biodegradability }\end{array}$ \\
\hline Nabinejad et al. [73] & $\begin{array}{c}\text { MWCNT }(0.2,0.4 \\
0.6,0.8 \text { wt. } \%)\end{array}$ & $\begin{array}{c}\text { Oil palm shell } \\
\text { powder (0-15 wt.\%) }\end{array}$ & Polyester resin & $\begin{array}{l}\text { (MEKP) } \\
1 \text { wt. } \%\end{array}$ & $\mathrm{D}$ & $\begin{array}{l}\text { Mechanical properties; } \\
\text { thermal properties }\end{array}$ \\
\hline Yaghoobi et al. [74] & $\begin{array}{l}\text { MWCNT (0.5, 1.0, } \\
1.5,2.0 \text { wt. } \%)\end{array}$ & Kenaf fibre (30 wt.\%) & $\begin{array}{c}\mathrm{PP} \\
(63-65 \text { wt. } \%)\end{array}$ & $\begin{array}{l}\text { MAPP } \\
(5 \text { wt. } \%)\end{array}$ & A & $\begin{array}{l}\text { Mechanical properties; } \\
\text { thermal properties }\end{array}$ \\
\hline Wang et al. [75] & $\begin{array}{c}\mathrm{GO}(0.05,0.1,0.3,0.5 \\
0.7 \text { wt. } \%)\end{array}$ & $\begin{array}{c}\text { Alkali-treated } \\
\text { bamboo fibre } \\
\text { (30 wt.\%) }\end{array}$ & PP (70 wt.\%) & None & $\mathrm{D}$ & $\begin{array}{l}\text { Mechanical properties; } \\
\text { thermal properties }\end{array}$ \\
\hline Song et al. [76] & $\begin{array}{c}\text { Pure CNTs or } \\
\text { CNTs-OH }(0.5,1 \text { or } \\
2 \text { wt. } \%)\end{array}$ & Wood flour (40 wt.\%) & $\begin{array}{c}\mathrm{PP} \\
(48-60 \text { wt. } \%)\end{array}$ & $\begin{array}{l}\text { MAPP } \\
(10 w t . \%)\end{array}$ & A & $\begin{array}{l}\text { Mechanical properties; } \\
\text { wettability }\end{array}$ \\
\hline
\end{tabular}

* Method of production according to Figure 2. ADCA: azodicarbonamide; MAPP: maleic anhydride-grafted polypropylene; MAPE: maleic anhydride-grafted polyethylene; MEKP: methyl ethyl ketone peroxide; PEI: polyethylenimine; PP: polypropylene; PE: polyethylene; HDPE: high-density polyethylene; PU: polyurethane; PES: polyethersulfone; PU: NCO-terminated PEG-pre-based polyurethane; ZnO: zinc oxide. 

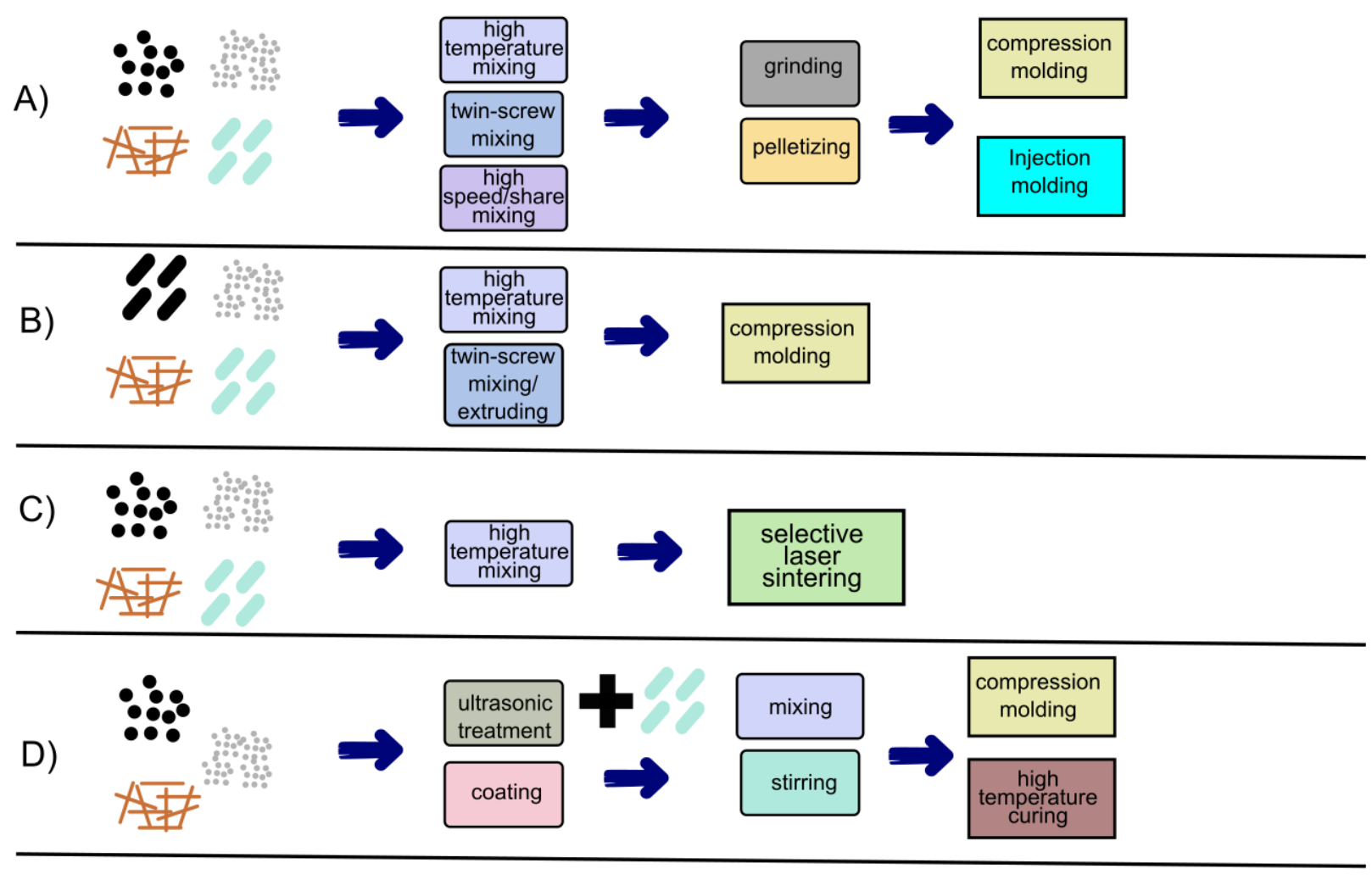
wood flour/
natural fiber masterbatch CNM

Figure 2. The scheme of various processes used when producing CNM-reinforced WPC. (A) compression/injection moulding with CNM powder, (B) compression moulding with CNM masterbatch, (C) selective laser sintering, (D) compression moulding/high temperature curing with wood flour coated with CNM suspension.

Table 1 also lists the composition of the WPCs/NFPCs, the type of CNM used, and the method of production (these production methods are explained graphically in Figure 2). It can be seen that the studied WPCs/NFPCs differed significantly in composition. The composites were based on thermoplastic [53,54,57] and thermoset matrices [70]; they used varying weight percentages of wood or cellulosic particles and different types of wood and cellulosic components as fillers [53-55,70]. Most of the composites included additives to facilitate the formation of high-performance materials $[53,54,63]$. Different composite manufacturing techniques were also proposed [53-55,70] (Table 1, Figure 2). The CNMs used in the studies shown in Table 1 included graphene nanoplatelets [70], functionalised graphenes [53], graphene oxides [61], reduced graphene oxides [58], carbon nanotubes (multiwalled) [54,55,68], and functionalised carbon nanotubes [77]. No less important is variety of techniques used for the incorporation of the CNMs.

This large variety of materials and manufacturing techniques indicates that the skilled incorporation of CNMs into WPCs/NFPCs may improve the properties of almost any of these composites. However, obtaining the optimal composition with its associated manufacturing method (one that will enable specific properties and levels of improvement to be achieved) is at present still challenging and difficult to foresee.

It has often been reported in the literature that the properties of WPCs/NFPCs depend strongly on their composition and manufacturing techniques [78-84]. In every study shown in Table 1, different base/reference materials are considered; therefore, we may expect variations in the properties observed. Similarly, the literature on CNM composites shows that the properties of the composites are dependent on the type, quality, and weight percentage of the CNMs, along with their compatibility with the matrix and the composite 
manufacturing method used [38,85-87]. As shown in Table 1, these factors are also changed significantly in the WPC/NFPC-CNM hybrids.

An in-depth comparative analysis of all of the papers listed in Table 1 enabled us to provide some general conclusions with regard to the design of the WPC/NFPC-CNM hybrids with specific properties, as well as indicating the areas for further research.

\subsection{Mechanical Properties}

To date, most publications in the area of WPC/FNPC-CNM hybrids have concentrated on their mechanical properties, either focusing the whole study on mechanical properties or performing mechanical tests alongside tests of other properties. Studies of mechanical performance mainly include tensile and flexural/bending tests; properties such as impact strength, storage and loss modulus, and scratch hardness also appear. In most cases, the improvements measured were in the range of single-digit percentages to tens of percent; however, occasionally they achieved improvements of hundreds of percent.

An example is a study by Sheshmani et al. [63], who reported enriching a WPC with graphene nanoplatelets. The WPCs were based on poplar flour, and used polypropylene and maleic anhydride-grafted polypropylene (MAPP) as coupling agents. In every composite, the poplar flour constituted $20 \mathrm{wt} . \%$, MAPP $3 \mathrm{wt} . \%$, and graphene $0.2,0.4,0.6,0.8,1,2,4$, or $5 \mathrm{wt} . \%$. The samples were prepared by mixing at an elevated temperature, grinding the cooled blends and, finally, compression moulding. It was found that the best improvement of mechanical properties was obtained at $0.8 \mathrm{wt} . \% \mathrm{GNP}$. The tensile strength and modulus increased by almost $20 \%$ with reference to a WPC without graphene. The flexural strength improved by $54 \%$, while the flexural modulus increased by $41 \%$. The elongation at break remained at the same level; however, the impact strength increased by $115 \%$.

For comparison, Ye et al. [61] manufactured samples with the addition of graphene oxide (GO). The base WPC was fabricated from polypropylene (PP), branched polyethylenimine (PEI), and recycled poplar powders. GO, PEI, and poplar powders were combined into PEI-wood-GO particles in a multistage sonication-assisted process. The PEI-woodGO particles were then mixed with PP, melted, and compounded in torque rheometers, with a ratio of $40 \mathrm{wt} . \%$ PEI-wood-GO and $60 \mathrm{wt} . \%$ PP. The weight fractions of GO in the final WPC were set at $0.1,0.2,0.3$, and $0.4 \%$. The presence of GO improved the mechanical properties of the composites. The tensile strength increased by $57.86 \%$, the elastic modulus by $48.92 \%$,the elongation at break by $70.17 \%$, the flexural strength by $26.31 \%$, and the flexural modulus by $75.21 \%$; the largest flexural force was increased by $21.89 \%$ with regard to the reference PEI-WPC.

Another example was published by Nourbakhsh et al. [54], who formed a set of samples using either poplar fibres or bagasse stalk with a polypropylene/MAPP coupling agent and MWCNTs. The ingredients were compounded by the use of a co-rotating twinscrew extruder, and then granulated and injection moulded. All samples included $40 \mathrm{wt} . \%$ percent natural fibres. The other $60 \mathrm{wt} . \%$ was divided between PP and MAPP (3 wt. $\%$ )-a reference sample —or PP, MAPP ( 3 wt. $\%)$, and MWCNTs (1.5, 2.5, or 3.5 wt. $\%)$. In most cases, the best results were obtained from a sample containing $2.5 \mathrm{wt} . \%$ MWCNTs. From these samples, rough estimations were produced based on the presented figures, and showed that for the poplar sample cases the tensile strength increased by almost $30 \%$ with regard to the reference sample ( $40 \mathrm{wt} . \%$ fibre, $57 \mathrm{wt} . \% \mathrm{PP}$, and $3 \mathrm{wt} . \% \mathrm{MAPP}$ ) with the addition of $2.5 \mathrm{wt} . \%$ MWCNTs. The tensile modulus increased by over $20 \%$, while the flexural strength and modulus were $7 \%$ and $9 \%$ higher, respectively. The impact strength appeared to be the highest for $1.5 \mathrm{wt} . \%$ content of MWCNTs, and increased by approximately $13 \%$ with regard to the reference sample. The mechanical properties of the bagasse samples were in most cases poorer than the poplar samples; however, all showed an increase in strength and stiffness upon the addition of MWCNTs.

Kushwaha et al. [77] presented WPC samples that differed from previously presented samples by virtue of the fact that they were prepared from bamboo strip mats rather than microparticles of wood/natural fibres. The bamboo mats were treated with an alkali prior 
to compounding with epoxy resin (CY-230), hardener (HY-951), and plasma-treated carbon nanotubes. The composites were prepared using a hand lay-up technique. The addition of plasma-treated CNTs produced an improvement in tensile strength $(6.67 \%)$, tensile modulus $(2.7 \%)$, flexural strength (5.8\%), flexural modulus (31\%), and impact strength $(84.5 \%)$.

The studies described above showed that an improvement in the mechanical properties may be obtained through the addition of different nanoforms of carbon with various natural fillers. However, the exact percentage improvement of specific properties differs from sample to sample (Figure 3).
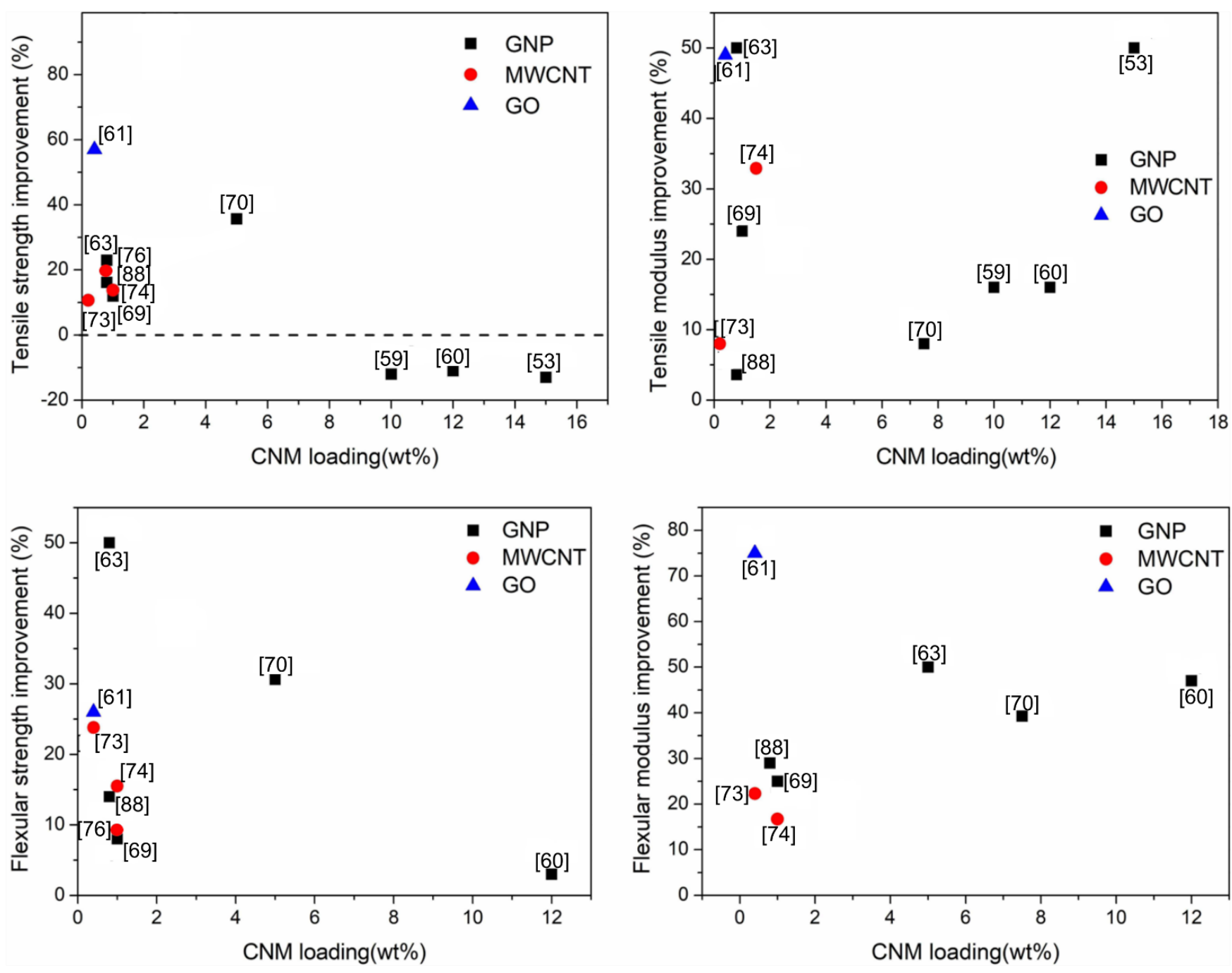

Figure 3. Mechanical properties of CNM-enriched WPCs, based on recent papers. The presented values present the best performing sample in each work.

An important conclusion of the work of Nourbakhsh et al. [54], who tested samples with different natural fillers, is that the properties of the base WPC may significantly affect the properties of the CNM-enriched composite. For example, the tensile strength of the base WPC with poplar wood fibres amounted to approximately $33 \mathrm{MPa}$, and for the bagasse stalk fibres approximately $31 \mathrm{MPa}$ - a relatively small difference. Analogous composites enriched with 2.5 wt.\% MWCNTs reached approximately $63 \mathrm{MPa}$ and $44 \mathrm{MPa}$ for poplarand bagasse-based samples, respectively. In the case of the tensile modulus, the initial values for the reference WPC samples showed a much larger difference (2008 $\mathrm{MPa}$ for the poplar sample and $3100 \mathrm{MPa}$ for the bagasse stalk sample), while the respective values for the $2.5 \mathrm{wt} . \%$ MWCNT-enriched samples changed by almost the same values-795 MPa and $768 \mathrm{MPa}$ for poplar and bagasse samples, respectively. 
The study of Kumar et al. [70] highlighted the fact that that the amount of natural filler is of importance. The samples were prepared via the mixing of LY-556 epoxy resin and HY-951 hardener (ratio of 10:1) with $0.5 \mathrm{wt} . \%$ GNP and 2.5, 5, 7.5, and $10 \mathrm{wt} . \%$ mixed wood particles. The mixture was then sonicated, degassed in a vacuum, poured into a mould, and polymerised under ambient conditions. The best mechanical performance was obtained for samples with $5 \mathrm{wt} . \%$ wood particles. For these samples, an increase in the tensile strength of $35.55 \%$ was observed, compared to samples without wood particles. The flexural strength increased by $30.64 \%$, hardness by $22.98 \%$, impact strength by $41.67 \%$, conductivity by $16.05 \%$, fracture toughness by $26.71 \%$, and fracture energy by $74.38 \%$. Unfortunately, as all of the samples contained $0.5 \mathrm{wt} . \%$ GNP, it was not shown how the amount of wood particles cooperates with the effect of the GNPs. It would be very useful to perform the same studies with various amounts of GNPs and without the CNM filler.

Ge et al. [64] tried to see how the overall performance of the composites is dependent on the ratio of wood particles to polymer matrix, as well as on the carbon nanomaterial type. The authors prepared a set of samples using 30, 40, or $50 \mathrm{wt} . \%$ decayed wood particles (Pinus massoniana Lamb), with $2 \%$ of the total mass of the chosen nanomaterial being either carbon nanotubes, graphene, activated carbon, or bamboo charcoal; $3 \mathrm{wt} . \%$ chitosan was also added with the aim of improving the interface properties of the composite, and polyvinyl chloride (PVC) was used as a matrix material. For the samples without any carbon filler, the highest values of damage load, bending strength, and elastic modulus were recorded for $40 \mathrm{wt} . \%$ wood particles; however, the tensile strength for this composition was the lowest. The addition of various carbon materials gave rather scattered results, both improving the absolute obtained values and decreasing them, as well as producing better results for $30 \mathrm{wt} . \%$ or $50 \mathrm{wt} . \%$ wood flour. This is an important result, and indicates that the natural and CNM fillers may influence the effectiveness of one another. The authors proposed that the optimal composition should be $40 \mathrm{wt} . \%$ wood particles, $60 \mathrm{wt} . \%$ PVC, with $2 \mathrm{wt} . \%$ CNTs and $3 \mathrm{wt} . \%$ chitosan. Indeed, this sample achieved the best tensile strength of all of the samples, and had better damage load and bending strength than any WPC sample without carbon-based reinforcement and sufficiently good elastic modulus.

Furthermore, Kaymakci et al. [67] showed that the effectiveness of CNMs in the improvement of WPC properties may be dependent on the presence of compatibilizers. Kaymakci et al. tested the surface roughness, wettability, and scratch properties of MWCNT-enriched WPCs. The samples were composed of 50/50 w/w pine wood flour and polypropylene. The MWCNTs constituted either 0 or 1, 3, or $5 \mathrm{wt} . \%$ of the composite. There were also two versions of the composites with MAPP ( $3 \mathrm{wt} . \%)$ and without MAPP. It was found that the increasing content of MWCNTs significantly decreases the surface roughness of the samples. The sole presence of MAPP also increases the effect; however, its impact is less than that of the nanotubes. The addition of both fillers produces almost the same surface roughness as in the case of MWCNTs alone (5 wt.\%). Both MAPP and MWCNTs decreased the wettability of the samples. The most beneficial change was in the presence of both MAPP and MWCNTs, as a superposition of both effects was observed; however, the effectiveness of MWCNTs slightly dropped when MAPP was present. The scratch hardness was also improved by both MWCNTs and MAPP; however, although it clearly increased with the content of MWCNTs, the increase induced by $5 \mathrm{wt} . \%$ CNTs was less than that of $3 \mathrm{wt} . \%$ MAPP. Again, the best results were obtained when the effects of both MAPP and MWCNTs were superimposed.

The study of Nabinejad et al. [73] showed that the method of manufacture of the hybrid WPC is very important. The samples were composed of oil palm shell powder (15 phr), an unsaturated polyester (UP) matrix, and various amounts of MWCNTs (0.2, 0.4, 0.6 , and $0.8 \mathrm{phr}$ ). The preparation method was performed with and without the aid of a solvent. The tested solvents included styrene, ethanol, methanol, and acetone. It was found that the most effective curing of the UP resin took place in the presence of styrene. Styrene samples achieved the highest tensile and flexural properties. 
Wang et al. [75] and Gouda et al. [88] claimed that the properties of their NFPCs improved thanks to the chemical modification of their natural bamboo fillers. Wang et al. [75] grafted GO into bamboo fibres treated with $1 \mathrm{wt} . \% \mathrm{NaOH}$. The mixture was then blended with melted PP and injection moulded. The tensile and flexural strength tests showed that the alkali treatment of the bamboo fillers improved the properties of the base WPC, and that the addition of GO further improved these parameters. However, no reference studies showing the performance of WPC with untreated bamboo fillers and GO were provided. Therefore, it is difficult to judge the influence of the alkali treatment of the bamboo filler on the GO's effectiveness. A similar conclusion may be drawn with regard to the study of Gouda et al. [88].

Most of the presented studies focused on the role of carbon nanomaterials and the methods of achieving the best performance with their use. As shown in the study of Ge et al. [64], the properties of hybrid WPCs are dependent on the type of carbon nanomaterial. However, it is important to mention that not only the type of carbon nanomaterial (CNTs, graphene, graphene oxide, etc.), but also the internal properties of the given CNMsuch as the number of layers/walls, length/diameter, defectiveness, etc.-may influence the properties of the composite [66]. The performance of a specific material is strongly related to the process of synthesis. At present there are few standards with regard to the manufacturing of carbon nanomaterials; therefore, similar materials made by various manufacturers may produce composites of different properties. This issue was partly covered by Al-Maqdasi et al. [53], who prepared WPC samples by the mixing of sawdust of spruce and pine wood with high-density polyethylene (HDPE), a compatibilizer-maleic anhydride-grafted high-density polyethylene (MAPE) — and two types of masterbatches of graphene platelets oxidised at the edges in HDPE. It was found that, overall, better results are obtained from a graphene M2 masterbatch with platelets of 6-10 layers and a flake size of $38 \mu \mathrm{m}$ than for an M1 graphene masterbatch with average thickness of $20 \mathrm{~nm}$ and flake size of $50 \mu \mathrm{m}$. These results show that for a sample containing $40 \mathrm{wt} . \%$ wood flour, the addition of $15 \mathrm{wt} . \% \mathrm{M} 2$ graphene caused the stiffness and yield strength to increase by $50 \%$ and $14 \%$, respectively. In the case of this study, GNPs also improved the flexural modulus; however, they had almost no influence on flexural and impact strength [89].

Several of the above papers note that the properties of the composites improved with the increased loading of CNMs. However, increasing the loading above a specific point led to a renewed reduction in the performance. In the case of Sheshmani et al. [63], the best mechanical performance was obtained with $0.8-1 \mathrm{wt} . \%$ graphene nanoplatelets. A higher loading of GNPs did not produce a sufficient improvement in the properties. A microscopic study showed that 3-5 wt.\% GNPs resulted in agglomeration of the nanomaterial and, therefore, a poorer performance of the composite. Analogous results were obtained by Nourbakhsh et al. [54], who found that the best mechanical properties of the samples were obtained for $2.5 \mathrm{wt} . \%$ MWCNT loading; a $3.5 \mathrm{wt} . \%$ loading of MWCNTs resulted in their agglomeration and, therefore, a much poorer stress transfer. Nabinejad et al. [73] showed that in the case of thermoset polymers an increase in the content of CNTs caused a very high increase in viscosity, and resulted in a very high void content; this also caused a reduction in the mechanical properties at high weight percentages of the CNTs.

To deal with this issue, Ye et al. [61] first combined the wood powders with GO using PEI in a multistage sonication-assisted process. The PEI-wood-GO particles were then combined with a PP matrix. It is rather difficult to judge how effective this process would be for higher loading fractions of GO, as the highest GO loading produced was $0.4 \mathrm{wt} . \%$.

Zhang et al. [55] prepared WPC samples via the selective laser sintering of polyether sulfone and pine wood powders (mass fraction ratio of 6:1). To improve the load transfer, the samples were subjected to additional microwave treatment. The authors explained that this treatment remelted the polymer matrix around the MWCNTs, improving the interface of the CNM and the matrix. In comparison, the addition of $0.1 \mathrm{wt} . \%$ MWCNTs to the basic process resulted in an approximately $90 \%$ increase in bending strength. Further microwave treatment of the samples increased the bending strength by another $4.2-64.2 \%$ with regard 
to the base laser-sintered CNT-enriched WPC. Again, in this case, the loading of the CNM was low.

It seems that the most effective method of dealing with the agglomeration of CNMs and poor load transfer was found by Al-Maqdasi et al. [53], who used masterbatches of graphene nanoplatelets oxidised at the edges. The oxidised graphene nanoplatelets were mixed with high-density polyethylene (HDPE), which was also used as a matrix for the prepared WPC. The loading fractions obtained by the authors were as high as $15 \mathrm{wt} . \%$, and the best mechanical properties were obtained for these loadings, indicating that no agglomeration took place.

The last issue to note with regard to loading-dependent changes in mechanical performance is the fact that the maximum improvement of different properties may take place for slightly different percentages of carbon fillers. This phenomenon may be described based on the studies of Yaghoobi et al. [72,74]. The tested composites were based on PP, MAPP, kenaf fibres, and MWCNTs. Premixed PP and MAPP powders were melted and blended with MWCNTs and kenaf fibres. Cooled blends were then hot-press-moulded. The samples contained $30 \mathrm{wt} . \%$ kenaf fibres, $5 \mathrm{wt} . \%$ MAPP, and 0-2 wt.\% MWCNTs. It was found that the addition of MWCNTs increased both the storage and loss moduli. The highest increases in tensile strength, flexural strength, and notched impact strength were observed for $1 \mathrm{wt} . \%$ MWCNTs, and amounted to $13.8 \%, 15.6 \%$, and $11.4 \%$, respectively. Meanwhile, the tensile and flexural moduli improved the most for $1.5 \mathrm{wt} . \%$ CNTs - by $18.9 \%$ and $17 \%$, respectively. The highest increases in the storage and loss moduli were also observed for $1.5 \mathrm{wt} \% \mathrm{CNTs}$. At $25^{\circ} \mathrm{C}$, the value of the storage modulus increased from $1995 \mathrm{MPa}$ to $2623 \mathrm{MPa}$, while for the loss modulus this was from $140 \mathrm{MPa}$ to $180 \mathrm{MPa}$. The above phenomenon may be explained by the different structural changes taking place during the varying mechanical tests. It should be noted that not all of them will be similarly affected by agglomeration or voids.

\subsection{Electrical and Thermal Conductivity}

It is important to highlight that in some cases agglomeration may not be an issue. It has been shown by several authors that WPCs may become electroconductive upon the addition of CNMs. The electrical conductivity of WPCs increases with the loading fraction of CNMs, and is not deteriorated by their poor distribution in the matrix. Zhang et al. [57] fabricated WPC samples from poplar wood fibres, polyethylene, and anhydride-grafted polyethylene (MAPE) as a coupling agent and lubricant, as well as either MWCNTs, flake graphite, or carbon black. The samples were prepared in a twin-screw one-step extruder system. The weight ratio of wood fibres to polyethylene was approximately $6: 4$ for all of the samples. The CNT weight percentages amounted to 3, 6, 9, and $12 \mathrm{wt} . \%$. Although larger weight percentages of CNTs were found to be detrimental to the mechanical properties, the electrical conductivity increased with the weight percentage of CNTs, and this reached the highest values for $12 \mathrm{wt} . \%$ (volume resistivity of $6 \times 10^{5} \Omega \cdot \mathrm{m}$ as compared to $10^{10} \Omega \cdot \mathrm{m}$ for reference sample).

Rajan et al. [59] obtained electrically conductive composites by mixing graphene nanoplatelets $(5,10$, or $15 \mathrm{wt} . \%)$ from a masterbatch (GNP in polypropylene), with a WPC masterbatch with 50/50 PP and a mix of spruce and fir wood flour, along with $3 \mathrm{wt} . \%$ of additives, including MAPP. The composites were prepared by melt compounding and hot pressing. The fabricated samples had either PP with $20 \mathrm{wt} . \%$ wood flour, PP with graphene, or PP with $20 \mathrm{wt} . \%$ of both flour and graphene. Although the authors used a masterbatch of GNP, the high loading of CNMs resulted in a decrease in tensile strength and only a small increase in the tensile modulus, which may potentially have been due to the lack of oxidation of the GNPs in the masterbatch. However, it was found that the highest tested loading of GNP (15 wt.\%) was the percolation threshold upon which the surface resistivity decreased to $2.90 \times 10^{6} \Omega /$ sq from $1.08 \times 10^{14} \Omega /$ sq for pure a WPC sample. This level enables the use of such composites as antistatic elements. 
In contrast to the case of electrical transport, a simple high loading fraction of CNMs may not be enough to obtain high thermal conductivity. Agglomeration is again an issue here. Referring to Rajan et al. [59], samples with $15 \mathrm{wt} . \%$ graphene increased the thermal conductivity by $135 \%$, although, as emphasised by the authors, the absolute values were still well below $1 \mathrm{~W} / \mathrm{mK}$, which is not sufficient for many applications. Analogous results were obtained by Zhang et al. [60], who manufactured composite samples from polyethylene, graphene nanoplatelets $(0,3,6,9$, or $12 \mathrm{wt} . \%)$, and poplar wood fibres $(40 \mathrm{wt} . \%)$, with maleic anhydride-grafted polyethylene (MAPE) as a compatibility agent (3 wt.\%). The components were dried, mixed, and extruded using a co-rotating twin-screw extruder. The thermal conductivity increased with the wt.\% of GNPs, becoming over 150\% larger for $12 \mathrm{wt} . \%$ GNPs than for the reference sample; however, it did not increase beyond $1 \mathrm{~W} / \mathrm{mK}$. The mechanical properties for such weight percentages of GNPs showed little increase in flexural strength and modulus, or in tensile modulus. However, the tensile strength and impact strength decreased, possibly indicating an agglomeration issue. The same authors [68] fabricated samples with MWCNTs $(0,3,6$, 9, or 12 wt.\%) instead of GNPs, along with an increased poplar wood fibre content $(60 \mathrm{wt} . \%)$. In the case of these samples, the mechanical properties were all worse than for pure WPC, and again the samples showed only a small increase in thermal conductivity (Figure 4). A measurement of thermal conductivity beyond $1 \mathrm{~W} / \mathrm{mK}(1.2 \mathrm{~W} / \mathrm{mK}$, for a sample of $40 \mathrm{wt} . \%$ wood particles and $15 \mathrm{wt.} \% \mathrm{GNP}$ ) was obtained by Al-Maqdasi et al. [53], indicating that good distribution of CNMs aids thermal transport in the samples.
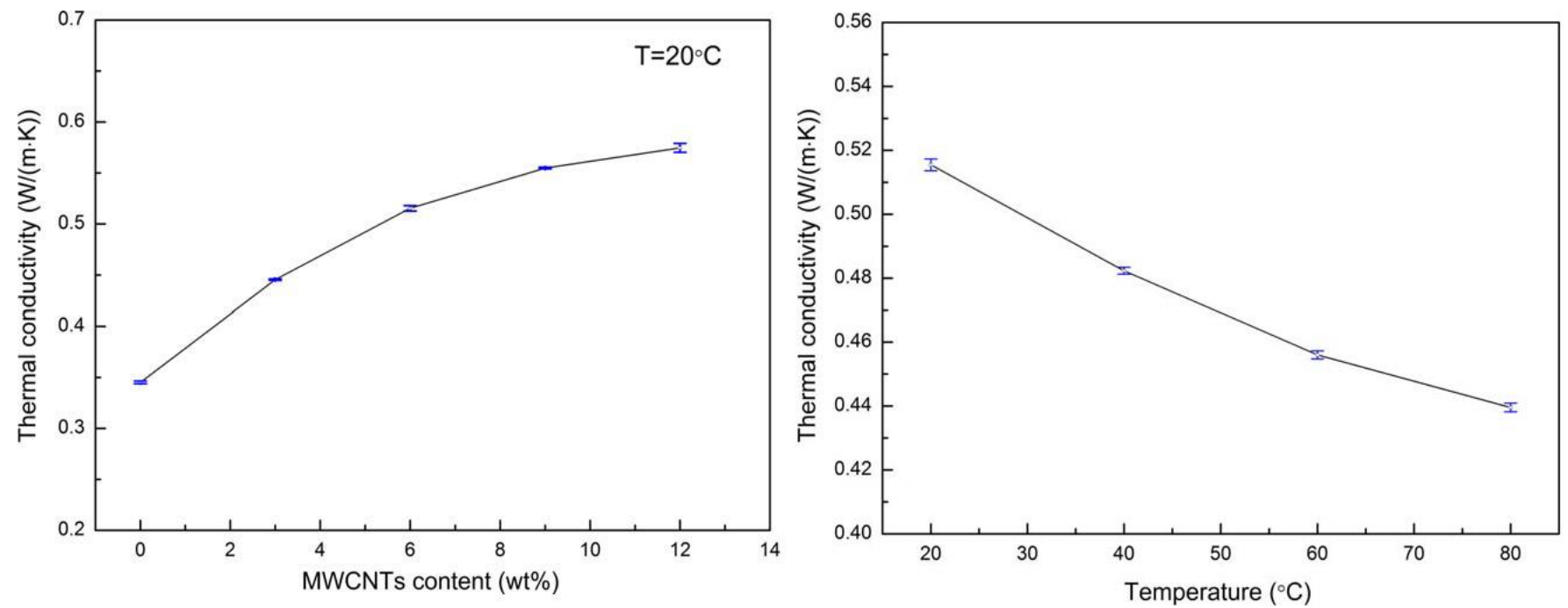

Figure 4. Dependence of the thermal conductivity of the WPCs on their MWCNT contents, and dependence of the thermal conductivity of the WPCs with $6 \mathrm{wt} . \%$ MWCNTs on temperature. Reprinted with permission from Wiley, copyright 2021 [68].

The most effective method of thermal conductivity improvement was found by Lu et al. [71]. Samples were prepared via the coating of pine wood fibres with graphene oxide, and then mixed with NCO-terminated PEG-pre polymer.and cured at $80^{\circ} \mathrm{C}$, which effectively produced GO-coated wood particles in a polyurethane matrix. It was clearly visible that the thermal conductivity of the composite increased with the weight percentage of GO, reaching the best values for $1.2 \mathrm{wt} . \% \mathrm{GO}$. However, a higher content of wood particles also contributed to an increase in the thermal conductivity, which was explained by the better percolation path formation, as shown in Figure 5. Effectively, the best result was observed for the sample with $1.2 \mathrm{wt} . \% \mathrm{GO}, 28.8 \mathrm{wt} . \% \mathrm{WP}$, and $70 \mathrm{wt} . \%$ PEG-pre polymer., and this amounted to $2.3 \mathrm{~W} / \mathrm{mK}$. 
(a)

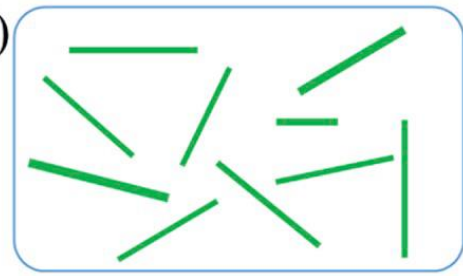

(b)

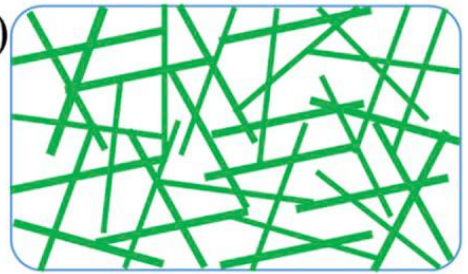

(c)

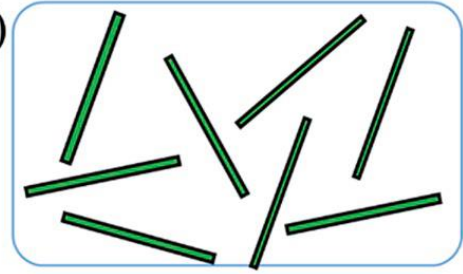

(d)

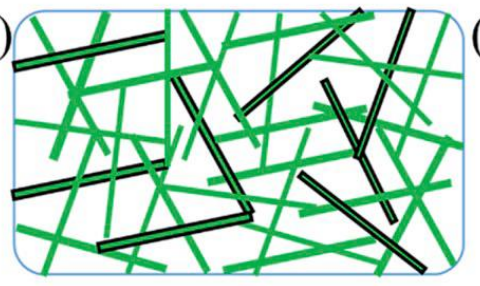

(e)

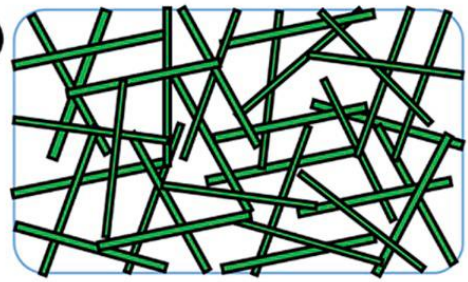

: SSPCMs : WP : GO

: WP@GO

Figure 5. Creating a thermally conductive network by incorporating wood WP and WP@GO into the SSPCM matrix. SSPCMs: PEG-based shape-stabilised phase change materials; WP: wood powder; GO: graphene oxide; WP@GO: wood powder coated with GO. (a) Low loading of WPs; (b) high loading of WPs, forming a 3D skeleton; (c,d) although GO is coating the WPs, the thermally conductive path cannot be formed yet; (e) formation of a thermally conductive pathway. Reprinted with permission from Elsevier, copyright 2021 [71].

A similar method for the coating of large-aspect-ratio components with CNMs was proposed by Chen et al. [58], who focused on the electrical properties and tested the possibility of producing composites for electromagnetic shielding, where the fillers were made of pure carbon fibres (CFs) and carbon fibres decorated with GO or rGO-although in the case of this study it must be taken into account that the CFs are also electrically conductive. GO and rGO were deposited on the CFs using the electrophoretic method. The cellulosic filler was made of corn straw (20 wt.\% in every composite). Polyvinyl chloride was used as a polymer matrix. All components were mixed and hot-pressed in a vulcanising machine. It was found that the samples with a $4 \mathrm{wt}$ \% content of CFs were the most effective in shielding; however, the use of $4 \mathrm{wt}$ \% decorated CFs gave even better results. The electrical conductivity of pure CF-WPC amounted to $4.5 \mathrm{~S} / \mathrm{m}$; for GO-CF$\mathrm{WPC}$ it was $6.2 \mathrm{~S} / \mathrm{m}$, while for $\mathrm{rGO}-\mathrm{CF}-\mathrm{WPC}$ it was $7.5 \mathrm{~S} / \mathrm{m}$. The rGO-CF-WPC also showed the best shielding effectiveness, with $29 \mathrm{~dB}$ compared to $23 \mathrm{~dB}$ for the CF-WPC (26\% increase).

\subsection{Photostability}

The study of Peng et al. [65] was the only one that focused on the photostability of CNM-enriched WPCs; this work also considered the effects of various kinds of carbon nanomaterials on the performance of the hybrid composites. The reference samples for the test were composed of poplar wood flour (40 wt.\%) and polypropylene (60 wt.\%). Furthermore, MWCNTs, graphite, or carbon black were added to the composites (2 wt.\% of the total mass). The materials were mixed and then extruded in a co-rotating twin-screw extruder, cut into pellets, and hot-pressed. The samples were then subjected to a $960 \mathrm{~h}$ accelerated UV weathering test. The mechanical properties test showed that the CNTenriched samples reached the highest values of flexural and impact strength both before and after weathering. All carbon materials decreased the photo-oxidation of the surface upon weathering; however, the CNTs also showed the least surface deterioration. The scanning electron microscope (SEM) images reprinted in Figure 6 show that the surface of pure WPCs starts to become rough after $240 \mathrm{~h}$, and clearly cracks after $480 \mathrm{~h}$. Samples reinforced with carbon black or graphite are more resistant to weathering, and show some deterioration features after $480 \mathrm{~h}$, while in the case of CNT-reinforced samples the cracks start to appear after $960 \mathrm{~h}$. The CNT-enriched samples additionally had the best colour 
stability, although it is worth mentioning that in all cases the carbon materials made the composite surface darker.
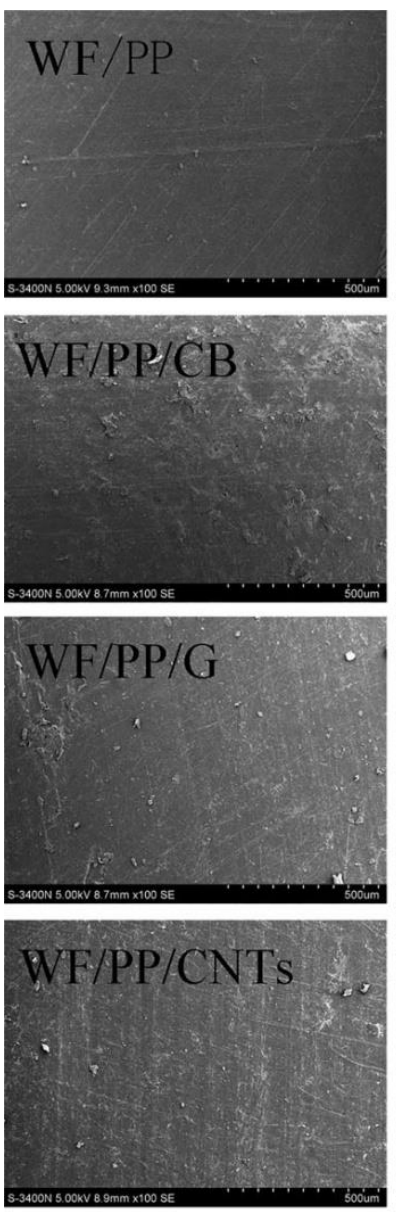

$0 \mathrm{~h}$
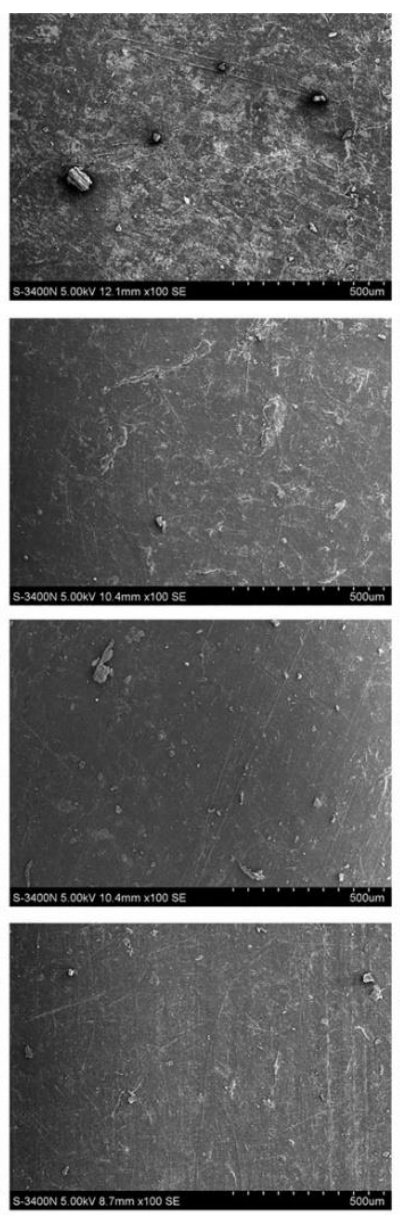

$240 \mathrm{~h}$
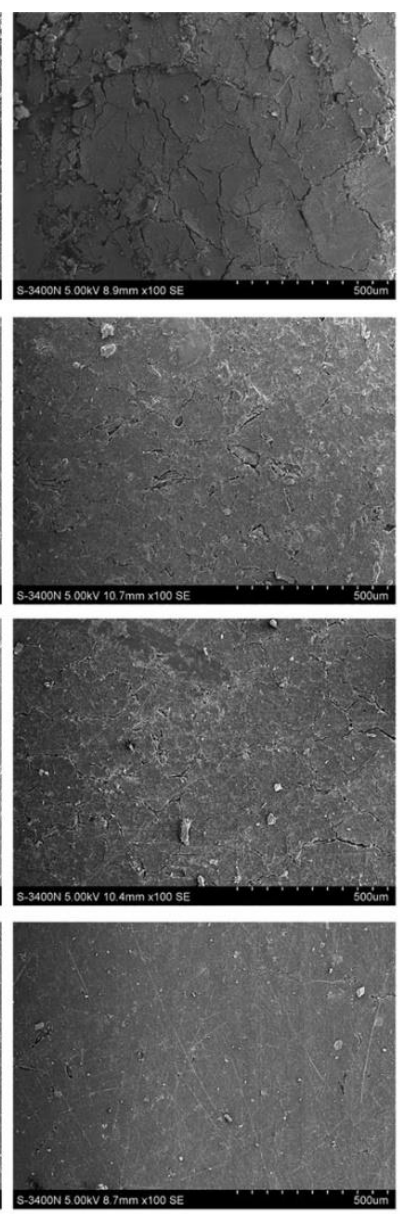

$480 \mathrm{~h}$
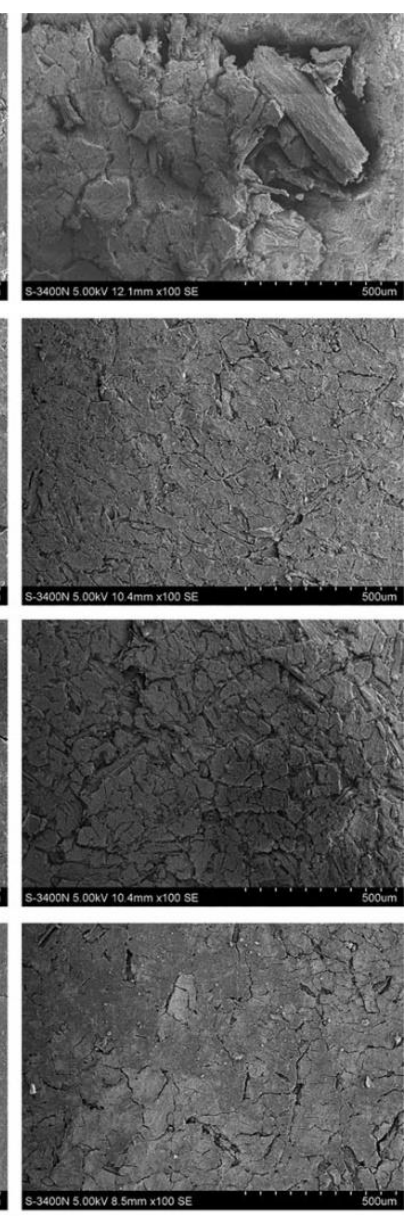

$960 \mathrm{~h}$

Figure 6. SEM images of the surface of pure WPCs (first row from the top) and below WPCs reinforced with carbon black $(\mathrm{CB})$, graphite $(\mathrm{G})$, and CNTs after different weathering times (WF/PP denotes wood flour/polypropylene). Reprinted by permission (Taylor \& Francis Ltd., http:/ / www. tandfonline.com) (accessed on 22 December 2021) [65].

\subsection{Water Absorption and Swelling Thickness}

As mentioned above (publication of Kaymakci et al. [67]), the presence of MWCNTs decreases the wettability of the samples, which may be related to the strong hydrophobicity of pure MWCNTs $[29,90]$. Many other authors have also shown that WPCs with CNMs are characterised by lower hydrophilicity and water uptake. It is worth noting that even oxidised CNMs, which should be much more hydrophilic, decreased the water or moisture uptake of WPC samples. Sheshmani et al. [63] showed that the addition of $0.8-1 \mathrm{wt} . \%$ GNPs decreased the water absorption of the samples by $35 \%$; as a result, the thickness swelling due to water uptake was diminished by $30 \%$. Ye et al. [61] found that the absorption value of a sample containing $0.4 \mathrm{wt} . \%$ GO immersed in water for $24 \mathrm{~h}$ amounted to only $1.13 \mathrm{wt} . \%$, while that of a reference amounted to $9.13 \mathrm{wt} . \%$. Kushwaha et al. [77] found that the presence of plasma-treated CNTs in the bamboo-strip-based composite samples resulted in a water uptake of $23.18 \%$, while reference samples absorbed $26.28 \%$ of water. Peng et al. [65] performed a 16-day-long water absorption test that resulted in a $2.65 \%$ water uptake for a CNT-containing sample and $3.14 \%$ for a pure WPC sample. It is worth mentioning that samples containing carbon black or graphite showed a lower water absorption than pure WPCs; however, they exhibited a higher water uptake than samples containing CNTs. 
Similarly CNT-enriched samples showed the least discoloration of all of the samples, both at room temperature and after a $60^{\circ} \mathrm{C}$ water wash. Al-Maqdasi et al. [53] showed that the presence of GNPs in WPC samples clearly decreased the stiffness and strain drop, due to water absorption.

\subsection{Thermal Stability and Flammability}

Many authors also performed a thermogravimetric analysis of their samples, showing better thermal stability of the composites. Sheshmani et al. [63] found that the best stability was obtained in a sample containing $0.8 \mathrm{wt} . \%$ GNPs; for this sample, the degradation temperature of the polymer matrix amounted to $430{ }^{\circ} \mathrm{C}$, while for the reference sample it was $330^{\circ} \mathrm{C}$. The authors explained that the non-agglomerated GNPs in the composite form a barrier, which delays the release and decomposition of volatile products. Ye et al. [61] found that the presence of $0.4 \mathrm{wt} . \%$ GO in the WPC sample increased the temperature of decomposition of both wood and polypropylene by approximately $70{ }^{\circ} \mathrm{C}$, and they explained this phenomenon in an analogous way. Ge et al. [64] - who compared samples with graphene, carbon nanotubes, bamboo charcoal, and activated carbon-emphasised the fact that the addition of any of these carbon materials slightly decreases the decomposition temperature of the WPCs due to the fact that the carbon allotropes have a higher decomposition temperature than the raw WPC. Zhang et al. found only a slightly better thermal stability of GNP- [60] and MWCNT [68]-enriched samples, which again could be related to the agglomeration issue found for high CNM content. The same authors also found that GNP-enriched samples showed increased fire retardancy, measured by the limiting oxygen index test. Furthermore, Fu et al. tested the thermal stability and flammability of carbon-nanotube-enriched WPC [62]; the samples were prepared from sawdust of poplar (40 wt.\%), $10 \mathrm{wt} . \%$ MAPP, and either pure CNTs or hydroxylated CNTs (CNT-OH) $(0.5,1$, or $2 \mathrm{wt} . \%)$, as well as polypropylene. Mechanical tests showed that the tensile strength increases slightly with the addition of CNTs or CNT-OH, and reaches the highest values for $0.5 \mathrm{wt} . \% \mathrm{CNT}$ or CNT-OH. However, the elongation at break decreases in all cases, which may indicate issues with agglomeration. This may be the reason for the best improvement in the thermal stability of the samples for $1 \mathrm{wt} . \%$ CNTs rather than for $2 \mathrm{wt} . \%$, along with the quite small changes in degradation temperature. For $1 \mathrm{wt} . \%$ $\mathrm{CNTs}$, the initial degradation temperature moved by $5{ }^{\circ} \mathrm{C}$, while the maximum weight loss temperature changed by $10^{\circ} \mathrm{C}$. Cone calorimeter tests showed that $1 \mathrm{wt} . \% \mathrm{CNTs}$ and CNT-OH could decrease the heat release rate by $16.7 \%$ and $25 \%$, respectively, while the total heat release rate decreased by $13 \%$ and $25 \%$ for CNTs and CNT-OH, respectively. However, the presence of $1 \mathrm{wt} . \% \mathrm{CNTs}$ and CNT-OH also slightly decreased the time to ignition, from $25 \pm 2 \mathrm{~s}$ to $23 \pm 2 \mathrm{~s}$.

\subsection{Foaming Efficiency}

Finally, an interesting paper by Ghalehno et al. [69] showed that graphene can also influence quite non-obvious properties of WPCs, such as their foaming efficiency at the manufacturing stage. Ghalehno et al. studied the formation of foamed WPCs formed from HDPE (50\%), industrial wood flour of up to $425 \mu \mathrm{m}$ diameter (50\%), maleic anhydridegrafted polyethylene as a coupling agent (2 parts per hundred of PE), azodicarbonamide as a foaming agent $(0,1$, or 3 parts per hundred of PE), and zinc oxide as a foaming agent activator (1.5 parts per hundred of azodicarbonamide). Some of the samples were also enriched with graphene nanoplatelets (1,2, or 4 parts per hundred of PE). The samples were first melt-compounded using a twin-screw extruder, and then foamed using a compression moulding machine. The presence of graphene in the samples clearly influenced the foaming. The GNPs formed more nucleation centres for bubble growth; as a result, there was less gas available for the cells to grow, which decreased the size of the bubbles. Simultaneously, the density of the cells increased. Consequently, the volumetric density of the WPC samples clearly decreased with the addition of GNPs with the same concentration of foaming agent. The addition of GNPs also improved the tensile and flexural strength and moduli of the 
composite. The best improvement was obtained for 1 phr of GNPs. Larger weight fractions of the GNPs were not as effective, which was attributed to agglomeration. Agglomeration did not influence the absorption properties of the samples. In accordance with previous studies (see also Section 2.4), the water uptake and related thickness swelling decreased steadily with the amount of GNPs.

\section{Applications}

As well as improving the performance of WPCs in current applications, we may also consider the enhancement of WPCs with new functionalities, allowing them to be used in completely new areas. For example, as indicated by Rajan et al. [59], an increase in the electrical conductivity may render the WPC's surface antistatic and simply prevent static electricity buildup in WPC constructions, or it may enable the use of WPCs in electronic packaging. Another application in this area may be the electromagnetic shielding studied by Chen et al. [58] (see also Section 2.2).

Moreover, WPCs filled with CNMs could potentially be used as sensors for temperature, water, or bending [91], although to the best of our knowledge they have not been tested for these applications to date.

Another property that may be utilised in new applications is thermal conductivity. Lu et al. [71] studied the thermal properties of wood-polymer composites enriched with GO (see also Section 2.2), with a view to creating a solar thermal energy storage device. The authors designed a shape-stabilised phase change material (SSPCM) composed of polyethylene glycol (PEG)-based polyethylene glycol-polyurethane (PU), wood fibres, and graphene oxide. The PEG-based PU was used as a phase change material with a high energy storage density, with the wood fibres acting as a scaffold, while the GO enhancement increased the thermal conductivity and light absorption. As a result, a device with good thermal stability and a light-thermal conversion performance was produced.

\section{Practical Considerations, Key Challenges, and Future Work}

Currently, WPCs are widely applied, and are mostly used in indoor and outdoor furniture and flooring, frames, fences, etc. The general improvement in their properties, such as increasing their strength, or decreasing their water uptake or flammability, may definitely be of interest to the current industry. Naturally, the obstacles here may be the introduction of CNMs into industrial production and the price of the final product. However, an analysis of market reports for carbon nanotubes shows that the polymer-CNT composites currently constitute the largest share of the market [92]. This indicates that the polymer industry is already well acquainted with carbon nanomaterials and the developed procedures for their incorporation into polymers, and these could be transferred to the industrial WPC production lines.

Our initial estimations of pricing indicate that, assuming the current market prices of CNTs, GNP, and GO, as presented in Table 2, for low weight percentages of CNMs the price of a $1 \mathrm{~m}^{2}, 2 \mathrm{~cm}$ thick WPC would not be increased significantly. Conversely, for high weight percentages (10 wt.\%), the current costs are estimated to be outside of commercial viability. However, taking into account that most studies use low filler contents, and that $1 \mathrm{~m}^{2}$ of WPC costs USD $\sim 100$, we can already see that the use of CNTs and graphene is quite feasible.

Table 2. Estimated prices of CNM additives to WPC.

\begin{tabular}{|c|c|c|c|c|}
\hline \multirow{2}{*}{ CNM } & \multirow{2}{*}{ Manufacturer } & \multirow{2}{*}{$\begin{array}{l}\text { Price per } \\
1 \mathrm{~kg} \text { (USD) }\end{array}$} & \multicolumn{2}{|c|}{$\begin{array}{c}\text { Estimated Price of CNM per } 1 \mathrm{~m}^{2} \text { of } \\
2 \mathrm{~cm} \text { Thick WPC (USD) }\end{array}$} \\
\hline & & & $\begin{array}{c}\text { with } \\
0.1 \text { wt. } \% \text { CNM }\end{array}$ & $\begin{array}{c}\text { with } \\
10 \text { wt. } \% \text { CNM }\end{array}$ \\
\hline CNTs & Nanocyl SA & 120 & 1.44 & 144 \\
\hline GNP & Cheap Tubes Inc. & 500 & 6.00 & 600 \\
\hline GO & Graphenea & 3300 & 39.60 & 3960 \\
\hline
\end{tabular}


However, before CNM-enriched WPCs or NFPCs can enter the market, there are still some significant scientific challenges that need to be addressed.

Sections 2.1-2.6 present the results of a variety of studies, showing that enriching WPCs and NFPCs with CNMs may be beneficial to their properties. Going forward, in future studies, a much more pragmatic approach to experimental planning needs to be adopted. It would be useful to consider the vast corpus of knowledge gathered in the manufacture of pure CNM and polymer composites [93-96], and to combine this with the state-of-the-art expertise already existing in the production of high-performance WPCs and NFPCs [97-99]. Such analysis could potentially help with the choice of specific CNMs, wood particles, compatible polymers, and methods of manufacture, as well as avoiding such issues as agglomeration or poor adhesion of components. The performance of modelling studies could also provide valuable insight.

It would also be useful to look at aspects such as density, which is a very basic property of every composite. To date, only Kumar et al. [92] and Rajan et al. [59] have provided data showing density changes with the content of CNMs. Kumar et al. showed that the density decreases linearly with an increase in GPC content, while Rajan et al. found the opposite trend. These discrepancies may be related to many factors, including large variations in the density of the chosen CNMs and issues related to the manufacturing of the composites, e.g., the formation of voids in the composites. Analysis of the density data could therefore be useful in the analysis of the quality of the composites, as well as in understanding the mechanisms responsible for their formation.

Taking into account the practical applications of WPCs and NFPCs, it would be also necessary to perform more studies on the weathering of hybrid samples. Apart from the UV exposure tested by Peng et al. [65] and the full water immersion effects studied by several authors (Section 2.4), weather-related degradation agents may include heat, humidity, rain erosion, freezing, and thawing. All of these factors separately or acting collectively may impact the mechanical, physical, and chemical properties of hybrid composites and, therefore, may change their visual appearance (e.g., colour, gloss) and their surface topography (e.g., roughness, surface microstructure), as well as affecting their strength, stiffness, dimensional stability, and overall service lifetime. Other degradation factors that should be considered, and have not been taken into account thus far, include fungi and mould, as well as decay/staining by air pollutants and saltwater.

More studies should also look into the issue of biodegradation. The only study dealing with this aspect to date, by Yaghoobi et al. [74], showed that enriching NFPCs with MWCNTs decreases the rate of biodegradation. This could be a very beneficial phenomenon; however, it could also be considered as a drawback when targeting the production of biodegradable composites [100,101].

Finally, it may be interesting and helpful to test the hybrid composites for acoustic properties, coatability, oil staining susceptibility, wear patterns, sand erosion, and performance under drilling. All of these properties are dependent on the specific application of the designed composites.

\section{Conclusions}

In summary, to date, a large variety of studies on WPCs/NFPCs hybridised with carbon nanomaterials have been presented. The composites were prepared using different types and amounts of wood flour and other forms of natural fillers, such as oil palm shell powder, kenaf fibres, bamboo mats, etc. The matrices were based on both thermoplastic and thermoset polymers. The composites were prepared both with and without additives such as MAPP and MAPE compatibilizers or selected hardeners. Various types of manufacturing techniques were also used, including twin-screw extrusion, compression moulding, and laser sintering. The WPCs/NFPCs were hybridised with graphene nanoplatelets, graphene oxides, MWCNTs, and functionalised CNTs, as well as CNM masterbatches.

Inclusion of the CNMs in the WPCs and NFPCs enabled the introduction of a relative improvement in the mechanical properties of the studied composites, such as tensile 
strength, flexural strength, and impact strength. The hybridisation with CNMs also enabled an increase in thermal conductivity. Furthermore, the addition of CNMs rendered WPCs electrically conductive, improved their thermal stability and decreased their flammability, increased their photostability, decreased their water absorption, and improved their foaming efficiency. However, the analysis of the studies showed that the level of improvement differed significantly between the hybrid WPCs/NFPCs, and that in some cases the improvement of one parameter was detrimental to another.

In the present review we have attempted to identify the factors that may influence the level of improvement of specific properties. These included the type, size, form, and amount of a natural filler, the presence of compatibilizers, the method of manufacture, and the type of carbon nanomaterials and their quality, as well as their amount and dispersion. In the context of carbon nanomaterials, their integration and dispersion was found to be particularly important, yet challenging. In most cases, a maximum improvement in properties was obtained at a maximum loading of CNMs, which did not cause agglomeration. The agglomeration taking place above this point was detrimental to the mechanical properties and the thermal stability. Only the electrical conductivity was found not to be sensitive to agglomeration. The distribution of CNMs was also a highly important factor for thermal conductivity. In this case, the best results were obtained for hierarchical structures where CNMs were deposited on elongated natural filler fibres.

It has been highlighted that the inclusion of CNMs may serve not only to improve the performance of WPCs/NFPCs, but also to enable the manufacture of products that may serve in new applications, such as WPC-based electromagnetic shielding or antistatic materials for electronic packaging. Furthermore, these new materials may be applicable for use in various sensors, heaters, and nanodevices.

Section 4 included some practical considerations such as costs, listed the key challenges, and identified areas for future research. The calculations demonstrated that hybrid composites should not be expensive to produce-a fact that should facilitate their rapid commercialisation. However, for the manufacture of the hybrid composites to be successful, any manufacturing needs to be preceded by further research leading towards better control over their properties. Similarly important would be the study of a wider range of degradation agents that can affect the performance of the hybrids.

\begin{abstract}
Author Contributions: Literature search, D.Ł.; literature analysis and article design, A.L.-R. and D.Ł.; writing-original draft preparation, A.L.-R.; scientific discussion and review, D.Ł., D.J. and P.H.-K.; writing — review and editing, J.P.; data visualisation, D.Ł.; graphics preparation (all figures aside from those where the copyright is cited), D.E. and G.W. All authors have read and agreed to the published version of the manuscript.
\end{abstract}

Funding: This research was funded by the National Centre for Research and Development, Poland (project no. TANGO-IV-A/0014/2019-00) and Warsaw University of Technology, Faculty of Mechatronics, Institute of Metrology and Biomedical Engineering.

Institutional Review Board Statement: Not applicable.

Informed Consent Statement: Not applicable.

Conflicts of Interest: The authors declare no conflict of interest.

\title{
References
}

1. Xu, K.; Du, G.; Wang, S. Wood Plastic Composites: Their Properties and Applications. In Engineered Wood Products for Construction; IntechOpen: London, UK, 2021.

2. Keskisaari, A.; Kärki, T. The use of waste materials in wood-plastic composites and their impact on the profitability of the product. Resour. Conserv. Recycl. 2018, 134, 257-261. [CrossRef]

3. Kazemi Najafi, S. Use of recycled plastics in wood plastic composites-A review. Waste Manag. 2013, 33, 1898-1905. [CrossRef] [PubMed]

4. Hao, X.; Sun, J.; Chen, C.; Zhou, H.; Li, Y.; Li, W.; Wang, Q.; Ou, R. Dimensional stability improvements of waste wood flour/HDPE composites via carbon black network embedding. Constr. Build. Mater. 2021, 299, 123955. [CrossRef]

5. Papadopoulos, A.N. Advances in Wood Composites. Polymers 2020, 12, 48. [CrossRef] [PubMed] 
6. Tokiwa, Y.; Calabia, B.P.; Ugwu, C.U.; Aiba, S. Biodegradability of Plastics. Int. J. Mol. Sci. 2009, 10, 3722-3742. [CrossRef]

7. Brebu, M. Environmental degradation of plastic composites with natural fillers-A review. Polymers 2020, 12, 166. [CrossRef]

8. Badji, C.; Soccalingame, L.; Garay, H.; Bergeret, A.; Bénézet, J.-C. Influence of weathering on visual and surface aspect of wood plastic composites: Correlation approach with mechanical properties and microstructure. Polym. Degrad. Stab. 2017, 137, 162-172. [CrossRef]

9. Wang, H.; Zhang, X.; Guo, S.; Liu, T. A review of coextruded wood-plastic composites. Polym. Compos. 2021, 42, 4174-4186. [CrossRef]

10. Fabiyi, J.S.; McDonald, A.G.; Wolcott, M.P.; Griffiths, P.R. Wood plastic composites weathering: Visual appearance and chemical changes. Polym. Degrad. Stab. 2008, 93, 1405-1414. [CrossRef]

11. Homkhiew, C.; Ratanawilai, T.; Thongruang, W. Effects of natural weathering on the properties of recycled polypropylene composites reinforced with rubberwood flour. Ind. Crops Prod. 2014, 56, 52-59. [CrossRef]

12. Mohammed, L.; Ansari, M.N.M.; Pua, G.; Jawaid, M.; Islam, M.S. A Review on Natural Fiber Reinforced Polymer Composite and Its Applications. Int. J. Polym. Sci. 2015, 2015, 243947. [CrossRef]

13. Luhar, S.; Suntharalingam, T.; Navaratnam, S.; Luhar, I.; Thamboo, J.; Poologanathan, K.; Gatheeshgar, P. Sustainable and Renewable Bio-Based Natural Fibres and Its Application for 3D Printed Concrete: A Review. Sustainability 2020, $12,10485$. [CrossRef]

14. Fogorasi, M.S.; Barbu, I. The potential of natural fibres for automotive sector-Review. IOP Conf. Ser. Mater. Sci. Eng. 2017, 252, 012044. [CrossRef]

15. Avci, E.; Acar, M.; Gonultas, O.; Candan, Z. Manufacturing biocomposites using black pine bark and oak bark. BioResources 2018, 13, 15-26. [CrossRef]

16. Russita, M. Bahruddin Production of palm frond based wood plastic composite by using twin screw extruder. IOP Conf. Ser. Mater. Sci. Eng. 2018, 345, 12039. [CrossRef]

17. Burgada, F.; Fages, E.; Quiles-Carrillo, L.; Lascano, D.; Ivorra-Martinez, J.; Arrieta, M.P.; Fenollar, O. Upgrading Recycled Polypropylene from Textile Wastes in Wood Plastic Composites with Short Hemp Fiber. Polymers 2021, 13, 1248. [CrossRef]

18. Carus, M.; Eder, A.; Dammer, L.; Korte, H.; Scholz, L.; Essel, R.; Breitmayer, E.; Barth, M. Wood-Plastic Composites (WPC) and Natural Fibre Composites (NFC): European and Global Markets 2012 and Future Trends in Automotive and Construction. Plast. Addit. Compd. 2015, 4, 18-21.

19. Bengtsson, M.; Oksman, K.; Stark, N.M. Profile extrusion and mechanical properties of crosslinked wood-thermoplastic composites. Polym. Compos. 2006, 27, 184-194. [CrossRef]

20. Mazela, B.; Hochmanska, P.; Letmann, M. Biological durability of wood plastic composites. Ann. Wars. Univ. Life Sci. SGGW Wood Technol. 2008, 64, 71-76.

21. Michalska-Pożoga, I.; Czerwińska, E. Effect of screw-disc extrusion process on the level of microbiological contamination of wood-plastic composites (WPC). Drewno 2015, 58, 65-73. [CrossRef]

22. Hosseinihashemi, S.K.; Badritala, A. The influence of a treatment process on the reaction to water of durable and water resistant wood/plastic composites. Drewno 2017, 60, 21-34. [CrossRef]

23. Kajaks, J.; Kalnins, K.; Naburgs, R. Wood plastic composites (WPC) based on high-density polyethylene and birch wood plywood production residues. Int. Wood Prod. J. 2018, 9, 15-21. [CrossRef]

24. Mathur, R.B.; Singh, B.P.; Pande, S. Carbon Nanomaterials: Synthesis, Structure, Properties and Applications, 1st ed.; Dresselhaus, M., Dresselhaus, G., Avouris, P., Eds.; Springer: Berlin/Heidelberg, Germany, 2001; ISBN 9781498702119.

25. Mandal, M.; Maitra, A.; Das, T.; Das, C.K. Graphene and Related Two-Dimensional Materials; Ashutosh Tiwari, M.S., Ed.; Wiley Online Books: Hoboken, NJ, USA; Scrivener Publishing LLC: Beverly, MA, USA, 2015; ISBN 9781119131816.

26. Allen, M.J.; Tung, V.C.; Kaner, R.B. Honeycomb Carbon: A Review of Graphene. Chem. Rev. 2010, 110, 132-145. [CrossRef] [PubMed]

27. Gorgolis, G.; Galiotis, C. Graphene aerogels: A review. 2D Mater. 2017, 4, 32001. [CrossRef]

28. Łukawski, D.; Lisiecki, F.; Dudkowiak, A. Coating Cellulosic Materials with Graphene for Selective Absorption of Oils and Organic Solvents from Water. Fibers Polym. 2018, 19, 524-530. [CrossRef]

29. Łukawski, D.; Lekawa-Raus, A.; Lisiecki, F.; Koziol, K.; Dudkowiak, A. Towards the development of superhydrophobic carbon nanomaterial coatings on wood. Prog. Org. Coat. 2018, 125, 23-31. [CrossRef]

30. Nine, M.J.; Cole, M.A.; Tran, D.N.H.; Losic, D. Graphene: A multipurpose material for protective coatings. J. Mater. Chem. A 2015, 3, 12580-12602. [CrossRef]

31. Xiong, G.Y.; Suda, Y.; Wang, D.Z.; Huang, J.Y.; Ren, Z.F. Effect of temperature, pressure, and gas ratio of methane to hydrogen on the synthesis of double-walled carbon nanotubes by chemical vapour deposition. Nanotechnology 2005, 16, 532-535. [CrossRef]

32. Bo, Z.; Yang, Y.; Chen, J.; Yu, K.; Cen, K. Nanoscale Plasma-enhanced chemical vapor deposition synthesis of vertically oriented graphene nanosheets. Nanoscale 2013, 5, 5180-5204. [CrossRef]

33. Mohan, V.B.; Lau, K.; Hui, D.; Bhattacharyya, D. Graphene-based materials and their composites: A review on production, applications and product limitations. Compos. Part B Eng. 2018, 142, 200-220. [CrossRef]

34. Dreyer, D.R.; Park, S.; Bielawski, C.W.; Ruoff, R.S. The chemistry of graphene oxide. Chem. Soc. Rev. 2010, 39, 228. [CrossRef] [PubMed]

35. Huang, X.; Qi, X.; Boeya, F.; Zhang, H. Graphene-based composites. Chem. Soc. Rev. 2012, 41, 666. [CrossRef] [PubMed] 
36. Pei, S.; Cheng, H.-M. The reduction of graphene. Carbon 2012, 50, 3210. [CrossRef]

37. Tasis, D.; Tagmatarchis, N.; Bianco, A.; Prato, M. Chemistry of carbon nanotubes. Chem. Rev. 2006, 106, 1105-1136. [CrossRef] [PubMed]

38. Bauhofer, W.; Kovacs, J.Z. A review and analysis of electrical percolation in carbon nanotube polymer composites. Compos. Sci. Technol. 2009, 69, 1486-1498. [CrossRef]

39. Chen, J.; Lekawa-Raus, A.; Trevarthen, J.; Gizewski, T.; Lukawski, D.; Hazra, K.; Rahatekar, S.S.; Koziol, K.K.K. Carbon nanotube films spun from a gas phase reactor for manufacturing carbon nanotube film/carbon fibre epoxy hybrid composites for electrical applications. Carbon 2019, 158, 282-290. [CrossRef]

40. Kinloch, I.; Suhr, J.; Lou, J.; Young, R.J.; Ayajan, P.M. Composites with carbon nanotubes and graphene: An outlook. Science 2018, 362, 6414. [CrossRef]

41. Lepak-Kuc, S.; Podsiadły, B.; Skalski, A.; Janczak, D.; Jakubowska, M.; Lekawa-Raus, A. Highly Conductive Carbon NanotubeThermoplastic Polyurethane Nanocomposite for Smart Clothing Applications and Beyond. Nanomaterials 2019, 9, 1287. [CrossRef]

42. Milowska, K.; Ghorbani-Asl, M.; Burda, M.; Wolanicka, L.; Catic, N.; Bristowe, P.; Koziol, K. Breaking the electrical barrier between copper and carbon nanotubes. Nanoscale 2017, 9, 8458. [CrossRef]

43. Ramírez, C.; Belmonte, M.; Miranzo, P.; Osendi, M.I. Applications of Ceramic/Graphene Composites and Hybrids. Materials 2021, 14, 2071. [CrossRef]

44. Wang, J.; Song, F.; Ding, Y.; Shao, M. The incorporation of graphene to enhance mechanical properties of polypropylene self-reinforced polymer composites. Mater. Des. 2020, 195, 109073. [CrossRef]

45. Kashiwagi, T.; Du, F.; Winey, K.I.; Groth, K.M.; Shields, J.R.; Bellayer, S.P.; Kim, H.; Douglas, J.F. Flammability properties of polymer nanocomposites with single-walled carbon nanotubes: Effects of nanotube dispersion and concentration. Polymer 2005, 46, 471-481. [CrossRef]

46. Łukawski, D.; Grześkowiak, W.; Mazela, B.; Lekawa, A.; Dudkowiak, A. The Influence of Surface Modification of Wood Particles with Carbon Nanotubes on Properties of Particleboard Glued with Phenyl-Formaldehyde Resin. Drewno 2019, 62, 93-105. [CrossRef]

47. Łukawski, D.; Grześkowiak, W.; Lekawa-Raus, A.; Widelicka, M.; Lisiecki, F.; Dudkowiak, A. Flame retardant effect of lignin/carbon nanotubes/potassium carbonate composite coatings on cotton roving. Cellulose 2020, 27, 7271-7281. [CrossRef]

48. Sreenivasulu, B.; Ramji, B.R.; Nagaral, M. A Review on Graphene Reinforced Polymer Matrix Composites. Mater. Today Proc. 2018, 5, 2419-2428. [CrossRef]

49. Barathi Dassan, E.G.; Anjang Ab Rahman, A.; Abidin, M.S.Z.; Akil, H.M. Carbon nanotube-reinforced polymer composite for electromagnetic interference application: A review. Nanotechnol. Rev. 2020, 9, 768-788. [CrossRef]

50. Wang, Q.; Wang, Y.; Meng, Q.; Wang, T.; Guo, W.; Wu, G.; You, L. Preparation of high antistatic HDPE/polyaniline encapsulated graphene nanoplatelet composites by solution blending. RSC Adv. 2017, 7, 2796-2803. [CrossRef]

51. Choi, J.H.; Lee, J.; Byeon, M.; Hong, T.E.; Park, H.; Lee, C.Y. Graphene-Based Gas Sensors with High Sensitivity and Minimal Sensor-to-Sensor Variation. ACS Appl. Nano Mater. 2020, 3, 2257-2265. [CrossRef]

52. Ke, Q.; Wang, J. Graphene-based materials for supercapacitor electrodes-A review. J. Mater. 2016, 2, 37-54. [CrossRef]

53. Al-Maqdasi, Z.; Gong, G.; Nyström, B.; Emami, N.; Joffe, R. Characterization of wood and Graphene Nanoplatelets (GNPs) reinforced polymer composites. Materials 2020, 13, 2089. [CrossRef]

54. Nourbakhsh, A.; Ashori, A.; Kargarfard, A. Evaluation of multiwalled carbon nanotubes as reinforcement for natural fiber-based composites. Polym. Compos. 2016, 37, 3269-3274. [CrossRef]

55. Zhang, Y.; Cui, Y.; Wang, S.; Zhao, X.; Wang, F.; Wu, G. Effect of microwave treatment on bending properties of carbon nanotube/wood plastic composites by selective laser sintering. Mater. Lett. 2020, 267, 127547. [CrossRef]

56. Zhang, X.; Hao, X.; Hao, J.; Wang, Q. Heat transfer and mechanical properties of wood-plastic composites filled with flake graphite. Thermochim. Acta 2018, 267, 127547. [CrossRef]

57. Zhang, X.; Hao, X.; Hao, J.; Wang, Q. Effect of the addition of carbon nanomaterials on electrical and mechanical properties of wood plastic composites. Polymers 2017, 9, 620. [CrossRef] [PubMed]

58. Chen, J.; Teng, Z.; Zhao, Y.; Liu, W. Electromagnetic interference shielding properties of wood-plastic composites filled with graphene decorated carbon fiber. Polym. Compos. 2018, 39, 2110-2116. [CrossRef]

59. Rajan, R.; Näkki, J.; Layek, R.; Rainosalo, E. Wood plastic composites with improved electrical and thermal conductivity. Wood Sci. Technol. 2021, 55, 719-739. [CrossRef]

60. Zhang, X.; Zhang, J.; Wang, R. Thermal and mechanical behavior ofwood plastic composites by addition of graphene nanoplatelets. Polymers 2019, 11, 1365. [CrossRef]

61. Ye, X.; Wang, H.; Tian, X.; Zhang, Y. Potential features of a 3D compatible polyethyleneimine-graphene oxide interface in WPCs via nano-self-assembly-modification. Polym. Compos. 2019, 40, 3233-3241. [CrossRef]

62. Fu, S.; Song, P.; Yang, H.; Jin, Y.; Lu, F.; Ye, J.; Wu, Q. Effects of carbon nanotubes and its functionalization on the thermal and flammability properties of polypropylene/wood flour composites. J. Mater. Sci. 2010, 45, 3520-3528. [CrossRef]

63. Sheshmani, S.; Ashori, A.; Arab Fashapoyeh, M. Wood plastic composite using graphene nanoplatelets. Int. J. Biol. Macromol. 2013, 58, 1-6. [CrossRef] 
64. Ge, S.B.; Gu, H.P.; Ma, J.J.; Yang, H.Q.; Jiang, S.C.; Liu, Z.; Peng, W.X. Potential use of different kinds of carbon in production of decayed wood plastic composite. Arab. J. Chem. 2018, 11, 838-884. [CrossRef]

65. Peng, Y.; Li, X.; Wang, W.; Cao, J. Photodegradation of wood flour/polypropylene composites incorporated with carbon materials with different morphologies. Wood Mater. Sci. Eng. 2020, 15, 104-113. [CrossRef]

66. Lepak-Kuc, S.; Milowska, K.Z.; Boncel, S.; Szybowicz, M.; Dychalska, A.; Jozwik, I.; Koziol, K.K.; Jakubowska, M.; Lekawa-Raus, A. Highly Conductive Doped Hybrid Carbon Nanotube-Graphene Wires. ACS Appl. Mater. Interfaces 2019, 11, 33207-33220. [CrossRef] [PubMed]

67. Kaymakci, A.; Birinci, E.; Ayrilmis, N. Surface characteristics of wood polypropylene nanocomposites reinforced with multiwalled carbon nanotubes. Compos. Part B Eng. 2019, 157, 43-46. [CrossRef]

68. Zhang, X.; Hao, X.; Hao, J.; Wang, Q. Thermal and mechanical properties of wood-plastic composites filled with multiwalled carbon nanotubes. J. Appl. Polym. Sci. 2018, 135, 46308. [CrossRef]

69. Ghalehno, M.D.; Kord, B. Preparation, characterization and performance evaluation of wood flour/ HDPE foamed composites reinforced with graphene nanoplatelets. J. Compos. Mater. 2020, 55, 531-540. [CrossRef]

70. Kumar, S.; Saha, A. Graphene nanoplatelets/organic wood dust hybrid composites: Physical, mechanical and thermal characterization. Iran. Polym. J. Engl. Ed. 2021, 30, 935-951. [CrossRef]

71. Lu, X.; Liang, B.; Sheng, X.; Yuan, T.; Qu, J. Enhanced thermal conductivity of polyurethane/wood powder composite phase change materials via incorporating low loading of graphene oxide nanosheets for solar thermal energy storage. Sol. Energy Mater. Sol. Cells 2020, 208, 110391. [CrossRef]

72. Yaghoobi, H.; Fereidoon, A. Evaluation of Viscoelastic, Thermal, Morphological, and Biodegradation Properties of Polypropylene Nano-Biocomposites Using Natural Fiber and Multi-Walled Carbon Nanotubes. Polym. Compos. 2018, 39, E592. [CrossRef]

73. Nabinejad, O.; Sujan, D.; Rahman, M.E.; Liew, W.Y.H.; Davies, I.J. Hybrid Composite Using Natural Filler and Multi-Walled Carbon Nanotubes (MWCNTs). Appl. Compos. Mater. 2018, 25, 1323. [CrossRef]

74. Yaghoobi, H.; Fereidoon, A. Preparation and characterization of short kenaf fiber-based biocomposites reinforced with multiwalled carbon nanotubes. Compos. Part B 2019, 162, 314. [CrossRef]

75. Wang, Q.; Zhang, Y.; Liang, W.; Wang, J.; Chen, Y. Improved mechanical properties of the graphene oxide modified bamboo-fiberreinforced polypropylene composites. Polym. Compos. 2020, 41, 3615. [CrossRef]

76. Song, P.A.; Yang, H.T.; Fu, S.Y.; Wu, Q.; Ye, J.W.; Lu, F.Z.; Jin, Y.M. Effect of carbon nanotubes on the mechanical properties of polypropylene/wood flour composites: Reinforcement mechanism. J. Macromol. Sci. Part B Phys. 2011, 50, 907-921. [CrossRef]

77. Kushwaha, P.K.; Pandey, C.N.; Kumar, R. Study on the effect of carbon nanotubes on plastic composite reinforced with natural fiber. J. Indian Acad. Wood Sci. 2014, 11, 82-86. [CrossRef]

78. Murayama, K.; Ueno, T.; Kobori, H.; Kojima, Y.; Suzuki, S.; Aoki, K.; Ito, H.; Ogoe, S.; Okamoto, M. Mechanical properties of wood/plastic composites formed using wood flour produced by wet ball-milling under various milling times and drying methods. J. Wood Sci. 2019, 65, 5. [CrossRef]

79. Cavus, V.; Mengeloğlu, F. Effect of wood particle size on selected properties of neat and recycled wood polypropylene composites. BioResources 2020, 15, 3427. [CrossRef]

80. Pokhrel, G.; Gardner, D.J.; Han, Y. Properties of Wood-Plastic Composites Manufactured from Two Different Wood Feedstocks: Wood Flour and Wood Pellets. Polymers 2021, 13, 2769. [CrossRef]

81. Guo, Y.; Zhu, S.; Chen, Y.; Li, D. Thermal Properties of Wood-Plastic Composites with Different Compositions. Materials 2019, 12, 881. [CrossRef]

82. Effah, B.; Van Reenen, A.; Meincken, M. Mechanical properties of wood-plastic composites made from various wood species with different compatibilisers. Eur. J. Wood Wood Prod. 2018, 76, 57-68. [CrossRef]

83. Mosavi-Mirkolaei, S.T.; Najafi, S.K.; Tajvidi, M. Physical and Mechanical Properties of Wood-Plastic Composites Made with Microfibrillar Blends of LDPE, HDPE and PET. Fibers Polym. 2019, 20, 2156-2165. [CrossRef]

84. Kumar, S.; Vedrtnam, A.; Pawar, S.J. Effect of wood dust type on mechanical properties, wear behavior, biodegradability, and resistance to natural weathering of wood-plastic composites. Front. Struct. Civ. Eng. 2019, 13, 1446-1462. [CrossRef]

85. Khan, Z.U.; Kausar, A.; Ullah, H.; Badshah, A.; Khan, W.U. A review of graphene oxide, graphene buckypaper, and polymer/graphene composites: Properties and fabrication techniques. J. Plast. Film Sheeting 2016, 32, 336-379. [CrossRef]

86. Li, Y.; Wang, Q.; Wang, S. A review on enhancement of mechanical and tribological properties of polymer composites reinforced by carbon nanotubes and graphene sheet: Molecular dynamics simulations. Compos. Part B Eng. 2019, 160, 348-361. [CrossRef]

87. Saravanan, N.; Rajasekar, R.; Mahalakshmi, S.; Sathishkumar, T.P.; Sasikumar, K.; Sahoo, S. Graphene and modified graphenebased polymer nanocomposites-A review. J. Reinf. Plast. Compos. 2014, 33, 1158-1170. [CrossRef]

88. Gouda, K.; Bhowmik, S.; Das, B. Thermomechanical behavior of graphene nanoplatelets and bamboo micro filler incorporated epoxy hybrid composites. Mater. Res. Express 2020, 7, 015328. [CrossRef]

89. Al-Maqdasi, Z.; Gong, G.; Nyström, B.; Joffe, R. Wood fiber composites with added multifunctionality. In Proceedings of the ECCM18-18th European Conference on Composite Materials, Athens, Greece, 24-28 June 2018; pp. 1-8.

90. Lau, K.K.S.; Bico, J.; Teo, K.B.K.; Chhowalla, M.; Amaratunga, G.A.J.; Milne, W.I.; McKinley, G.H.; Gleason, K.K. Superhydrophobic Carbon Nanotube Forests. Nano Lett. 2003, 3, 1701-1705. [CrossRef]

91. Łukawski, D.; Dudkowiak, A.; Janczak, D.; Lekawa-Raus, A. Preparation and applications of electrically conductive wood layered composites. Compos. Part A Appl. Sci. Manuf. 2019, 127, 105656. [CrossRef] 
92. Market Analysis. Available online: https://www.gminsights.com/industry-analysis/carbon-nanotubes-market (accessed on 11 February 2022).

93. Liu, F.; Hu, N.; Zhang, J.; Atobe, S.; Weng, S.; Ning, H.; Liu, Y.; Wu, L.; Zhao, Y.; Mo, F.; et al. The interfacial mechanical properties of functionalized graphene-polymer nanocomposites. RSC Adv. 2016, 6, 66658-66664. [CrossRef]

94. Niyobuhungiro, D.; Hong, L. Graphene Polymer Composites: Review on Fabrication Method, Properties and Future Perspectives. Adv. Sci. Technol. Res. J. 2021, 15, 37-49. [CrossRef]

95. Ma, P.-C.; Siddiqui, N.A.; Marom, G.; Kim, J.-K. Dispersion and functionalization of carbon nanotubes for polymer-based nanocomposites: A review. Compos. Part A Appl. Sci. Manuf. 2010, 41, 1345-1367. [CrossRef]

96. Chen, J.; Yan, L.; Song, W.; Xu, D. Interfacial characteristics of carbon nanotube-polymer composites: A review. Compos. Part A Appl. Sci. Manuf. 2018, 114, 149-169. [CrossRef]

97. Yáñez-Pacios, A.J.; Martín-Martínez, J.M. Surface modification and adhesion of wood-plastic composite (WPC) treated with UV/ozone. Compos. Interfaces 2018, 25, 127-149. [CrossRef]

98. Rao, J.; Zhou, Y.; Fan, M. Revealing the Interface Structure and Bonding Mechanism of Coupling Agent Treated WPC. Polymers 2018, 10, 266. [CrossRef] [PubMed]

99. Hejna, A.; Przybysz-Romatowska, M.; Kosmela, P.; Zedler, Ł.; Korol, J.; Formela, K. Recent advances in compatibilization strategies of wood-polymer composites by isocyanates. Wood Sci. Technol. 2020, 54, 1091-1119. [CrossRef]

100. Sommerhubera, P.F.; Wenkera, J.L.; Rütera, S.; Krause, A. Life cycle assessment of wood-plastic composites: Analysing alternative materials and identifying an environmental sound end-of-life option. Resour. Conserv. Recycl. 2017, 117, 235. [CrossRef]

101. Winandy, J.E.; Stark, N.M.; Clemons, C.M. Considerations in recycling of wood-plastic composites. In Proceedings of the 5th Global Wood and Natural Fibre Composites Symposium, Kassel, Germany, 27-28 April 2004; p. 9. 